\title{
Review
}

\section{The Epidermis: Redox Governor of Health and Diseases}

\author{
Yosuke Ishitsuka ${ }^{1, *(1)}$ and Dennis R. Roop ${ }^{2}$ \\ 1 Department of Dermatology Integrated Medicine, Osaka University Graduate School of Medicine, \\ 2-2 Yamadaoka, Suita, Osaka 565-0871, Japan \\ 2 Charles C. Gates Center for Regenerative Medicine, Department of Dermatology, \\ University of Colorado Anschutz Medical Campus, Aurora, CO 80045, USA; dennis.roop@cuanschutz.edu \\ * Correspondence: ishitsuka@derma.med.osaka-u.ac.jp; Tel.: +81-66-879-3031; Fax: +81-66-879-3039
}

Citation: Ishitsuka, Y.; Roop, D.R. The Epidermis: Redox Governor of Health and Diseases. Antioxidants 2022, 11, 47. https://doi.org/ $10.3390 /$ antiox 11010047

Academic Editors: Hye-Youn Cho and Steven R. Kleeberger

Received: 27 November 2021

Accepted: 25 December 2021

Published: 26 December 2021

Publisher's Note: MDPI stays neutral with regard to jurisdictional claims in published maps and institutional affiliations.

Copyright: (C) 2021 by the authors. Licensee MDPI, Basel, Switzerland. This article is an open access article distributed under the terms and conditions of the Creative Commons Attribution (CC BY) license (https:// creativecommons.org/licenses/by/ $4.0 /)$.

\begin{abstract}
A functional epithelial barrier necessitates protection against dehydration, and ichthyoses are caused by defects in maintaining the permeability barrier in the stratum corneum (SC), the uppermost protective layer composed of dead cells and secretory materials from the living layer stratum granulosum (SG). We have found that loricrin (LOR) is an essential effector of cornification that occurs in the uppermost layer of SG (SG1). LOR promotes the maturation of corneocytes and extracellular adhesion structure through organizing disulfide cross-linkages, albeit being dispensable for the SC permeability barrier. This review takes psoriasis and AD as the prototype of impaired cornification. Despite exhibiting immunological traits that oppose each other, both conditions share the epidermal differentiation complex as a susceptible locus. We also review recent mechanistic insights on skin diseases, focusing on the Kelch-like erythroid cell-derived protein with the cap " $n$ " collar homology-associated protein 1/NFE2-related factor 2 signaling pathway, as they coordinate the epidermis-intrinsic xenobiotic metabolism. Finally, we refine the theoretical framework of thiol-mediated crosstalk between keratinocytes and leukocytes in the epidermis that was put forward earlier.
\end{abstract}

Keywords: cornification; genetic diseases; loricrin; KEAP1/NRF2 signaling; epidermal differentiation complex; psoriasis; atopic dermatitis; Langerhans cells

\section{Introduction and Overview}

\subsection{What Is Cornification for?}

Cornification is an ultimate form of body wall protection [1], in which molecules are packaged (cross-linked), secreted, and then degraded (desquamation). Although keratinization is a shared differentiation program among stratified squamous epithelia that cover wet surfaces (particularly in the hard palate, tongue papilla, or vagina), keratinocytes in the interfollicular epidermis or the follicular infundibulum are exclusively allowed to form the stratum corneum (SC) [2]. Indeed, this imprinting impedes the terminal differentiation of keratinocytes in submerged cultures [3], even if they are freshly isolated from the epidermis. Implantation of epidermal keratinocytes into the immunocompromised host [4] or exposure to the air-liquid interface with the aid of fibrocyte-laden collagen matrix beneath (organotypic culture) [5] allow their differentiation into fully matured phenotypes. With regards to the organotypic setting, however, the anuclear layers that mimic SC continue to pile up without shedding off presumably due to the incomplete development of the secretory system located beneath the SC [5]. Therefore, "true" cornification appears to require constant crosstalk between the epidermal keratinocytes and the surrounding niche (microenvironment) [6].

The differentiation program of epidermal keratinocytes starts following the exit from the proliferative layer (stratum basale) and detachment from the basement membrane [7]. Microenvironmental cues, such as the calcium gradient [8], vitamin D [9], or vitamin A [10,11], profoundly affect cellular fate. The uppermost living layers, stratum granulosum (SG), where the functional cell death program [12,13] takes place, denote 
anatomical importance. Before being completely flattened and enucleated, the keratinocyte cell membrane is replaced by a specialized structure called cornified cell envelopes (CEs), which is a macromolecular structure composed of protein and lipids [14]. Transglutaminase enzymes catalyze the covalent cross-linkage [ $\varepsilon$ - $(\gamma$-glutamyl $)$ lysine cross-linkage]. The powerful covalent bond is also seen in stabilizing collagen, elastin, or blood clotting [2]. The earlier phase of CE assembly is mandatory for endowing the SC with waterproof property [2,15]. Additionally, transglutaminase 1 [16], CE precursors envoplakin/periplakin/involucrin (IVL) [17], and desmosomal components [18-20] appear indispensable. Findings from mouse models correlate with inborn errors in humans [21-23], both of which exhibit aberrantly activated immune responses [20,22] secondary to the compromised epidermal barrier. SC's compromised inside-out/outside-in permeability barrier function, maintained by interstitial lamellated lipids and adhesion molecules [24], has a pathogenic role. It is thus reasonable that the "leaky" SC promotes pathogen sensing of antigen-presenting cells [25] in the uppermost living layer SG, where dendritic cells (DCs) express tight junction (TJ) proteins and sample self [26] or non-self [27] antigens $[28,29]$. Common loss-of-function (LOF) variants in the filaggrin (FLG) gene are an established susceptibility factor for chronic eczema (atopic dermatitis; AD) [30]. The genotype, which is responsible for the common dry skin (ichthyosis vulgaris) [31], decreases the amount of humectant stored in corneocytes and lowers the threshold of local inflammatory responses [32,33]. However, with the contribution of environmental factors [34], FLG-deficiency causes AD, ultimately leading to the sequelae of allergic conditions (atopic march) $[35,36]$. Premature skin peeling (desquamation) may irritate the skin more directly. Desmosomal defects in the SC, caused either by structural defects or enhanced proteolysis, lead to atopic diatheses, such as multiple food allergies [21,22] or Staphylococcus aureus (S. aureus) colonization [37]. The compromised barrier function can evoke $\mathrm{T}_{\mathrm{H}}$ 17-type adaptive immune responses [38]. Staphylococcal colonization is a typical feature of AD [39], and exfoliative toxins target the key adhesion component desmoglein 1 (DSG1) in the SG [40]. Therefore, the "leaky" SC further aggravates local inflammatory responses despite the "preemptive" adaptive immunity [41], constituting an integral part of AD's vicious cycle.

\subsection{Revisiting Epidermal Sulfur Metabolism}

The evidence mentioned above highlights the importance of the "mortar" [42] for maintaining skin health and diseases, particularly when focusing on AD pathology [43]. Nonetheless, we need to acknowledge the fundamental principle of cornification, i.e., the metabolism of sulfur; thiol (-SH) groups of the proliferative epidermal layer are converted into strong covalent (-S-S-) bridges of the keratin molecule [44]. Disulfide (-S-S-) bonds reinforce the robustness that protects against a myriad of external insults, such as ultraviolet (UV) rays [45-47] or electrophiles [48-50]. Not surprisingly, the rudiment is applied to various surface epithelia, such as the squamous mucosa [51], the bronchial epithelium [52,53], or even the gut epithelium [54,55]. Either the excess [55] or the insufficiency [53] of disulfide on the barrier surface leads to the development of pathologies. Loricrin (LOR), which is named after the "lorica" - meaning armor in Latin-[56], is an essential effector of cornification that executes disulfide-mediated cross-linkages [57]. Gene knockout studies have revealed that LOR is nonessential for the "mortar" [15,58] (Figure 1). Nonetheless, the sulfur-rich, major CE constituent protects against harmful stimuli [2]. The findings may epitomize the LOR's indispensable role as an armor, as the name connotes [56], in terrestrial lifestyles. In a similar vein, the squamous epithelia are equipped with the Kelch-like erythroid cell-derived protein with the cap " $n$ " collar homology-associated protein 1 (KEAP1)/NFE2-related factor 2 (NRF2) signaling pathway [59], which enables prompt xenobiotic responses in the differentiated layers of the squamous epithelium [60]. Dysregulation in the epidermal cellular reduction/oxidation (redox) apparatus can lead to many kinds of skin diseases while being tissue-protective in most situations [60]. In the tissue-protective scenario, we have found that small proline-rich proteins (SPRR2) [57] or late cornified envelope proteins (LCE1) [61] are direct downstream targets of the KEAP1/NRF2 signaling pathway. Given 
that the epidermal differentiation complex (EDC) is one of the rapidly evolving genetic clusters among terrestrial vertebrates $[60,62]$, the antioxidative backup response appears to help amniotes withstand arid terrestrial environments by promoting tissue repair.

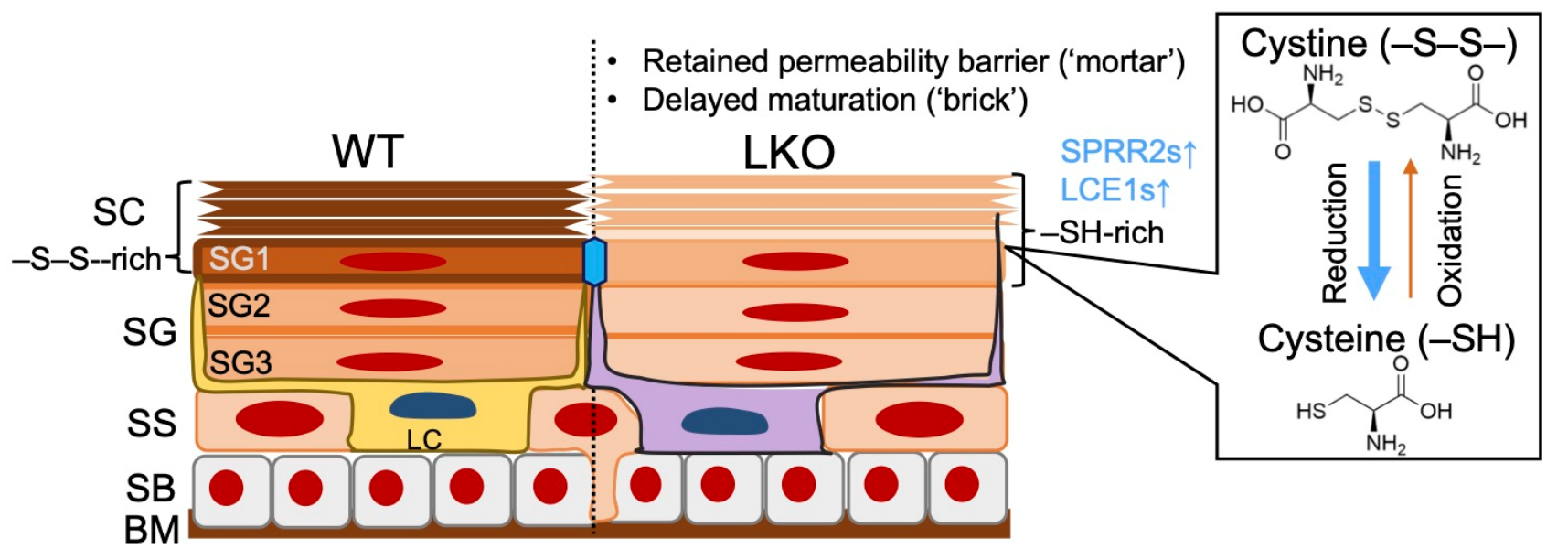

Figure 1. Schematic representation of loricrin-knockout (LKO) epidermis. A thiol (-SH) gradient through the epidermis provides unparalleled cytoprotection, and cornification involves prompt and organized disulfide (-S-S-) cross-linkages. Loricrin is a major effector of cornification, and differentiated layers of LKO epidermis are mechanically compromised despite the presence of other components, such as small proline-rich proteins 2 (SPRR2s) and late cornified cell envelope proteins 1 (LCE1).

In this review, we take psoriasis and $\mathrm{AD}$, in which cornification is impaired, and epidermal redox imbalance plays a pathological role $[48,63]$. Intriguingly enough, despite somewhat opposing traits $[64,65]$, they share the susceptible genetic loci EDC that harbors the NRF2-downstream target genes [60]. We also review recent mechanistic insights on cornification by focusing on LOR and the KEAP1/NRF2 signaling pathway, as they coordinate the epidermis-intrinsic xenobiotic metabolism $[2,15,60]$. Finally, we refine the theoretical framework of thiol-mediated crosstalk between keratinocytes and leukocytes in the epidermis that had been put forward earlier $[2,60,66]$.

\section{Epidermal Differentiation and Skin Diseases}

\subsection{Psoriasis}

Psoriasis is a chronic, immune-mediated skin disease that affects approximately $3.2 \%$ of the adult population in the United States regardless of sex differences [67]. Genetic components significantly impact psoriasis pathogenesis. The classic human leukocyte antigen (HLA)-Cw6 allele on the psoriasis-susceptibility 1 (PSORS1), activating variants in the caspase recruitment domain family member 14 (CARD14) on the PSORS2, TRAF3 interacting protein 2 (TRAF31P2) on the PSORS13, LOF variants in interleukin-36 receptor antagonist protein (IL36RN) on the PSORS14, or the protective IL-23 receptor allele may represent the immune-driven nature of psoriatic diseases (Online Mendelian Inheritance in Man (OMIM), accessed on 18 November 2021 [68]). As the remarkable success of immunotherapies targeting the IL-23/IL-17 pathway [69] denotes, inhibiting the rapid polymorphological neutrophil influx that occurs in a noncognate fashion [70] (i.e., the psoriasiform tissue reaction [71]) is likely to be the therapeutic key. Its close association with major histocompatibility class I, such as HLA-Cw6 or HLA-B27 alleles, indicates the autoimmune aspect of this chronic inflammatory condition [72,73]. However, unrestrained innate immune responses (autoinflammation) remain an essential pathological component because nonspecific stimuli, such as trauma, bacterial/viral infection, or drugs, evoke tissue imprinted immunological memory [74]. The quintessential clinical observation is the Köbner phenomenon [75]. Rodent models are vital tools for drug development and experi- 
mental pathology. For instance, the HLA-B27 transgenic rat [76], the vascular endothelial growth factor [77]/signal transducers and activators of transcription 3 [78] transgenic mice, the Il36rn [79]/Il1rn [80] -knockout mice, psoriasis xenograft [81], and topical imiquimod (IMQ) (toll-like receptor 7 agonist) application [82] have revealed important aspects of the pathology of psoriatic diseases. Overall, the success of translational medicine has made psoriasis one of the most successful target diseases in dermatology in recent years [83].

\subsubsection{EDC and Psoriasis}

In addition to neutrophil infiltration, psoriasis is characterized by hyperplasia and truncated differentiation of the epidermal tissue. Because cellular growth and differentiation are usually exclusive of each other, growth inhibition through blocking nucleic acid synthesis, e.g., methotrexate [67] or epidermal growth factor signaling pathway [84], may rationalize therapeutic efficacy. However, the hyperproliferative psoriatic epidermal phenotype accompanies a distinct immunologically "active" phenotype, in which IL-17producing, retinoic acid-receptor-related orphan receptor gamma (ROR $\gamma$ )-positive skin resident memory T-cells are enriched [85,86]. Although orally [87] or topically [88] administered vitamin D3 analogs primarily affect the immune system, the fundamental effects on keratinocyte behavior, i.e., inhibiting proliferation [89] and promoting differentiation [9,90], reflect the reversal of the diseased epidermal phenotype. Albeit psoriasis and AD exhibit defective cornification [65], despite their opposing immunological traits, they share risk loci in proximity within the EDC: PSORS4 for psoriasis and ATOD2 for AD [64].

The EDC gene cluster spans $1.6 \mathrm{Mb}$ of the $1 \mathrm{q} 21$ human chromosome (mouse 3q) [91], and comprises three gene clusters that encode the following: (i) CE precursor proteins IVL, LOR, SPRRs, and the LCE; (ii) S100 calcium-binding proteins containing EF-hand domains; (iii) and the "fused gene" proteins (S100 fused type proteins), such as FLG, hornerin, and repetin that evolved from (i) and (ii) [60]. Given that CE precursor genes, such as the $\beta$-globin genes, are supposed to have evolved from common ancestors [92], the host's adaptive responses on the body surface may have resulted in gene duplication/deletion, ultimately shaping pathologies, such as in sickle cell anemia for the $\beta$-globin gene cluster [60]. The $L C E 3 B-L C E 3 C$ deletion represents a psoriasis risk allele in the EDC [93]; however, no other genes, including LOR [94] and FLG [95], have been proven as susceptibility genes. Thus, the $L C E 3 B$-LCE3C deletion allele should have some selection advantages to evolve as a psoriasis-susceptibility gene [96].

\subsubsection{Antimicrobial Properties of the "Alternative" CE Precursors LCEs}

The supposed common origin of the CE precursor genes [92] and the apparently normal-looking phenotype [58] of LOR-knockout (LKO) mice prompted us to investigate other candidates that should be replenished to compensate for the absence of the major CE protein LOR [61]. CE amino acid composition analysis suggested that the candidate should be rich in glycine and serine [97], as well as harbor potential transglutaminase crosslinking sites both in the carboxy and the amino termini [61,92]. This reasoning led us to identify LCE1s, which are located within the LCE gene cluster, as NRF2-downstream target genes [61], as with SPRR2s [57]. These "alternative" CE precursors or "LOR-mimicry" have a generally small molecular weight (approximately $10 \mathrm{kDa}$ ) and are robustly induced in response to external stress, such as UVB irradiation, wound healing, and tape-stripping [60]. It is thus reasonable to assume that SPRRs or LCEs are instrumental in protecting against skin surface injuries, and the LKO phenotype may reflect such an adaptive response in the epidermis [15]. In humans, likewise, it appears that LCE3s are particularly sensitive to such micro-injuries $[93,98]$, albeit no significant correlation between the LCE3B-LCE3C deletion allele and the Köbner phenomenon has been noted [99]. Nonetheless, the LCEs function as antimicrobial peptides [100], as also noted in the other small molecular weight CE precursor SPRRs [101,102]. In this scenario, the LCE3B-LCE3C deletion results in the transcriptional upregulation of LCE3A, which has exhibited high levels of $\beta$-defensin-like broad antimicrobial activity in vitro among the LCE3 family [100]. Considering that psoriasis was indeed 
an exaggerated protective antimicrobial immune response, the upregulated defensin-like activity on the squamous epithelia, including oral mucosa (tonsil/gingiva/pharynx) [60,98], might have protected against invasive streptococcal infections, such as scarlet fever [103]. The inherent molecular property of the LCE that is induced as a result of superficial injuries (and the backup response in LKO mice) [61,93], in combination with the HLA-Cw6 allele-driven immune component, possibly rendered the LCE3B-LCE3C deletion as the only recurrent psoriasis risk allele within the EDC (PSORS4) [96,104].

\subsection{Atopic Dermatitis}

$\mathrm{AD}$, also called eczema, is the most common inflammatory skin disease that involves early age onset, persistent itch, a relapsing disease course, and which affects $5 \%$ to $10 \%$ of adults and $10 \%$ to $13 \%$ of children in the United States [105]. AD reduces the quality of life by compromising sleep quality, work/school associated productivity, interpersonal problems, and self-esteem [105]. AD's salient immunological trait involves the predominance of type 2 immunity, characterized by the increased risk of local bacterial/viral/fungal infection and systemic IgE-mediated humoral immunity [39]. Epithelium-derived type 2-associated cytokines, such as thymic stromal lymphopoietin (TSLP), IL-25, and IL-33, allow noncognate, local expansion of group 2 innate lymphoid cells, which are a potent producer of IL-13 in the local tissue [106]. Percutaneous exposure of protein antigens promotes B-cell production of high-affinity $\operatorname{IgE}$, which is regarded as the culprit of systemic anaphylaxis [107]. The adaptive immune system plays a pivotal role in this pathogenic compartment; $\mathrm{T}$ follicular helper cells producing IL4/IL-13 provide cognate help for B cells to maturate [107].

IL-1 $\alpha$ [108] and IL-33 [109] are alarmins that belong to damage-associated molecular patterns that indicate tissue injury contracted by the host [110]. IL-1 $\alpha$ possesses strong costimulatory activity and is abundantly expressed in epidermal keratinocytes [108,111]. In the SC of AD patients with LOF FLG variants, IL- $1 \alpha$ is more abundantly expressed compared to cases without FLG mutations [112]. Thus, as the vicious cycle of itch and excoriation (itch-scratch cycle) in AD patients suggests, the epidermal release of danger signals secondary to the defective SC barrier, caused by FLG-deficiency [113] or premature skin peeling [114], appears to be the essential element of AD pathology.

Mouse studies have suggested that house dust mites [115], peanut allergens [116], or microbiota [117-119], as well as mechanical injuries [119-122], promote the epidermal release of the alarmins. TSLP signaling constitutes a critical element in initiating allergic inflammation [123]. TSLP acts on DCs [124,125] and allows innate lymphoid cells to expand in the skin [126]. Importantly, TSLP serves as a communication module between epithelial cells and sensory neurons that express transient receptor potential ankyrin 1 , thus evoking persistent itch [127]. This evidence makes the TSLP-signaling pathway an attractive therapeutic target in AD [128].

Treatment options for AD had been limited until the emergence of a therapeutic IL4/IL-13 signaling blockade that utilizes dupilumab, a fully human monoclonal antibody targeting the IL-4 receptor $\alpha$ [129]. Dupilumab improves disease activity by suppressing local/systemic type 2 inflammation and ultimately promoting epidermal differentiation recovery (cornification) [130]. Therefore, dupilumab appears to reverse most of the pathological elements observed in the type 2 inflammation of the skin. However, other emerging therapeutic targets, such as TSLP [128], the "itchy" cytokine IL-31 [131], and Janus kinases [132], will provide a breadth of therapeutic opportunities for AD patients in the future [83].

\subsubsection{AD and the FLG Variant}

The FLG gene encodes a pro-FLG protein, which harbors tandemly arranged repeats of FLG monomers [113]. During the transition from the SG to the SC, i.e., cornification [1], the huge pro-FLG protein undergoes proteolytic cleavage following dephosphorylation (extensively reviewed in [113]). FLG monomers are then incorporated CEs, ultimately leading to 
the generation of natural moisturizing factors that are primarily composed of hygroscopic amino acids in corneocytes [133]. Thus, despite the name connoting the aggregation of intermediate filaments [134], FLG's primary function is to maintain corneocyte humidity. Indeed, inborn errors in the FLG-breakdown cascade, as well as LOF FLG variants, lead to ichthyotic phenotypes with varied severity and modes of inheritance (OMIM, accessed on 18 November, 2021 [68]).

Ichthyosis vulgaris is the most common inherited disorder of keratinization, and one of the most frequent single-gene disorders in humans [31]. In 2006, Mclean et al. found that the R501X and 2282del4 variants in the FLG gene, which lead to the complete absence of gene expression, are a major predisposing factor for AD in European ancestry [30]. Although the prevalence of FLG variants shows geographical as well as ethnic differences [135], no other EDC genes [136] have been identified as strong predisposing genes. Although FLG-knockout mice have dry, scaly skin and faithfully model the ichthyosis vulgaris phenotype, they do not develop spontaneous AD-like inflammation, even when they are maintained on the BALB/c background [32,137], a high IgE responder. In contrast, the "flaky tail" mice, which harbor spontaneous homozygous frameshift mutation 5303delA in repeat 6 of FLG, develop eczema, elevated serum IgE levels [138], and local expansion of group 2 innate lymphoid cells that produce IL-5 when maintained on the BALB/c background [139]. Despite FLG genotypes having been reportedly associated with impaired lamellar granule (LG) secretion and decreased levels of tight junction protein expression in humans [140], there might be other confounding factors, apart from those related to the external environment, that affect the interstitial space in the SC [137]. Mouse studies suggest that a nonsense mutation Y208Stop in transmembrane protein 79 (TMEM79), identified in the "flaky tail" mice [141,142], results in spontaneous skin inflammation that is exaggerated in the BALB/c background [139]. Indeed, it has been found that the missense single nucleotide polymorphism in TMEM79 is common among AD patients [141].

TMEM79 is expressed in the trans-Golgi network in the SG, and thus affects the secretory function of LGs [142], which is the prerequisite for SC permeability barrier function [42]. Moreover, TMEM79 regulates mast cell-mediated histaminergic itch, which depends on synergetic effects between keratinocytes and sensory neurons in mice [143]. Moreover, a Xenopus study suggested that the transmembrane TMEM79 protein affects the ectodermal development through the wingless/fizzled signaling pathway, thus revealing a significant impact on the development of integumentary system [144]. Aggregation of evidence suggests the possibility that the "outside-in" hypothesis of AD pathogenesis is not as straightforward as initially anticipated [2].

\subsubsection{AD and Corneocyte Adhesion}

Cornification begins with the extracellular release of adhesion molecules packaged in LGs to the interstitial space of the SC located apically [2]. Specifically, the homophilic adhesion molecule corneosesmosin (CDSN) plays an essential role. CE replaces keratinocyte cell membrane, and CDSN binds to the outer cell surface, along with long-chain $\omega$-hydroxyceramides that form corneocyte lipid envelopes [2]. After establishing the lipidrich outercoat, CEs connect CDSN via disulfide cross-linkages, and serin protease-mediated proteolysis ensues [145]. Meanwhile, corneocytes keep becoming flattened as they migrate upwards [146] and finally detach from the skin surface [147]. Therefore, successful cornification involves well-coordinated skin peeling (desquamation), which occurs at the very end of the epidermal differentiation [15].

The molecular genetics on inborn errors of skin peeling provides a profound insight into the pathogenesis of AD [148]. Netherton syndrome (NS) is an autosomal recessive trait characterized by ichthyosiform erythroderma, hair shaft abnormality, and atopic manifestations. The patients are born with erythroderma that develops into ichthyosis linearis circumflexia. In addition to eczematous skin lesions, systemic complications are also common, such as failure to thrive (FTT), systemic infection, eosinophilia, increased serum IgE levels, and food allergy [148]. NS is caused by LOF mutations in the serine protease 
inhibitor of Kasal-type 5 (Spink5) gene that encodes lymphoepithelial Kazal-type related inhibitor type 5 (LEKTI). Unopposed proteolytic activity of serine protease kallikreins (KLKs) leads to the degradation of the extracellular domain of DSG1 and CDSN, thus upregulating TSLP in the epidermis [148]. Although Spink5-knockout mice exhibit SC detachment and postnatal lethality from dehydration [149], epidermal KLK5 transgenic mice faithfully replicate major symptoms of NS [150]. LOF mutations in the CDSN gene cause autosomal recessive genodermatosis peeling skin syndrome 1 (PSS1), whose symptoms involve ichthyosiform erythroderma, FTT, increased IgE levels, eosinophilia, asthma, urticaria/angioedema, and food allergy [148]. Currently, two independent gene knockout studies of CDSN have been reported [151,152], both of which result in postnatal lethality that phenocopies the Spink5-knockout mice [149]. LOF mutations in the DSG1 gene promote loss of membrane expression of DSG1, thus leading to skin dermatitis, multiple severe allergies, and metabolic wasting (SAM) syndrome [22,148], whose clinical features comprise striate palmoplantar keratoderma, as well as FTT and atopic manifestations similar to NS or PSS1. DSG1-knockout mice exhibit postnatal lethality due to a superficial detachment of the epidermal tissue $[19,20]$, albeit exhibiting $\mathrm{T}_{\mathrm{H}} 17$-associated inflammatory signatures at embryonic day 18.5 (right before birth) [20]. Thus, results from the rodent models and SAM syndrome patients may correspond to immunological alertness (preemptive immunity [41]) augmented by the breach of superficial epidermal tissue [153].

\subsection{3. $\mathrm{AD}$ as an Antioxidative Response in the Epidermis}

As mentioned above, the disrupted SC barrier appears to constitute the major pathogenic element in AD that is followed by systemic foreign antigen-specific IgE responses [36]. Although type 2 inflammation dominates AD pathology, $\mathrm{T}_{\mathrm{H}} 17$ (or type 17) inflammation does have pathogenicity in AD [154], particularly at the disease onset [155].

Because we had characterized the role of the KEAP1/NRF2 signaling pathway that compensates for the loss of a major CE protein LOR [57,61], we examined whether NRF2 activation ameliorates psoriasiform tissue reaction evoked by topical IMQ application [82], in which neutrophil influx to the upper epidermis impairs cornification [71]. Indeed, NRF2knockout mice suffered exaggerated type 17 responses, including increased expression levels of tumor necrosis factor, IL6, IL23, and IL17a [63]. An electrophile dimethyl fumarate (DMF) is an anti-psoriatic drug that has been empirically used in Europe, and which has recently become a Food and Drug Administration (FDA)-approved drug for relapsingremitting multiple sclerosis (MS) [156], which is also a $\mathrm{T}_{\mathrm{H}}$ 17-driven autoimmune disease. Oral DMF administration resulted in protection from ear swelling responses and increased cytokine expression levels, while NRF2-knockout mice responded much less robustly than the wild-type control [63]. The same tissue-protective effects of the KEAP1/NRF2 signaling pathway were observed in the context of tape-stripping-induced recovery responses in LKO [15] or Spink5-knockout mice [157]. The repairing response appears to involve NRF2-mediated upregulation of antimicrobial defense [158] or LG secretory function [15]. NRF2 activation can be detrimental, as postnatal lethality of KEAP1-knockout mice [159] or ichthyotic/chloracne-like phenotypes in constitutively active NRF2 transgenic mice [160] suggest. Therefore, we utilized contact hypersensitivity (CHS) allergic responses against the small molecule called hapten. Haptens are usually electrophilic, and their hydrophobic properties determine the outcome of CHS; hydrophobic (lipophilic) haptens cause irritancy to the uppermost epidermal living layer SG during downward penetration, while innoxious haptens do less [161]. NRF2-knockout mice mounted much weak local immediate-type reactions (a model of urticaria/anaphylaxis) [162], and epidermal keratinocyte harbored a relatively small amount of IL- $1 \alpha$ that initiates type 2 immune response [48]. Given that the SC causes "sterile" inflammation when implanted intradermally [163], augmentation of NRF2-mediated antioxidative defense appears to initiate the allergic response in the skin [48]. Indeed, high IL-1 $\alpha$ expression levels are observed in AD with LOF FLG mutations [112], NS [164], or lamellar ichthyosis [165], as well as the "flaky tail" mice [119], in addition to high NRF2 expression levels $[48,57,158]$. Earlier mouse studies have sug- 
gested that both IL-1 $\alpha[166]$ and NRF2 $[50,167,168]$ protect against chemical carcinogens. Likewise, the protective function of IgE against cancers has been suggested both epidemiologically [169] and experimentally [170-172]. Therefore, antioxidative response occurring at the frontline defense system could inform the immune system regarding cellular dysregulations [171], which can be caused by not only electrophilic chemicals $[48,172]$ but also physical injuries [173], such as UV [47], helminth infection [169], or AD (also called itch that rashes) [48] as well. In summary, it appears that the epidermis converts a myriad of physical threats into biochemical signaling via the KEAP1/NRF2 system, a thiol-mediated sensor-effector apparatus [59].

\section{Redox Regulators of Skin Health and Diseases}

The protective, differentiated layers of the epidermis are sulfur-rich, and the formation of the heavily disulfide cross-linked appendages, such as the SC, claws (nails), feathers, or hair on the skin surface differentiates amniotes from other vertebrates [174]. In contrast, aquatic mammals appear to have lost such armaments required for terrestrial life. A phylogenetic study suggested that type I/type II keratin gene clusters in cetaceans do not contain $\mathrm{K} 1 / \mathrm{K} 10$ (that produces the SC), along with other genes for hair, nail, and tongue papillae, as opposed to basal keratins $\mathrm{K} 5 / \mathrm{K} 14 / \mathrm{K} 9$ and stress-associated keratins K6/K16/K17 [175]. Evidence suggests that terrestrial life requires sulfur-rich apparatus as a protective shield (against UV rays or xenobiotics). Conversely, aquatic life prioritizes rapid wound healing since there are no physical threats (and dehydration).

\subsection{LOR, the "Finisher" of Cornification}

Through meticulous ultrastructural observation, we found that LOR is a major CE protein accumulated in the inner cell periphery, and NRF2 upregulates LG secretory functions that lead to increased CDSN expression levels [15]. In the absence of LOR, however, apparently normal-looking corneocytes retained desmosomes, which should be degraded as going upward [147]. These results suggest that cell-intrinsic NRF2 activation in LKO mice maintains SC permeability function and upregulates keratinocyte antioxidants SPRR2s/LCE1s [57,61]. The other important finding is that LOR promotes the structural maturation of desmosomes in the SC (corneodesmosomes). Because LKO mice do not exhibit thickened SC, as in the case of the psoriatic or palmoplantar epidermis [176,177], LOR promotes disulfide-mediated cross-linkages of CDSN to the outer surface of corneocyte. This is in line with our previous findings that LKO CE is less efficient in disulfide-mediated cross-linkages of K1/K10 that are anchored to desmosomes [178]. Collectively, LOR is nonessential for maintaining the SC permeability barrier function unless it acquires the nuclear localizing signal [179], but it is indispensable for the structural maturation of corneocytes $[45,58,178]$.

\section{2. "Structural Imprinting" of the Cutaneous Immune Effector Functions}

In addition to the desmosome that connects adjacent keratinocytes via keratin intermediate filament, the TJ barrier is indispensable for maintaining the inside-out permeability barrier of the epidermis. Impaired TJ function caused by LOF mutations in claudin-1 (CLDN1) causes ichthyosis and sclerosing cholangitis in humans [180], and CLDN1-knockout mice die postnatally from dehydration [181] and develop AD-like features when the expression is systematically regulated [182]. Cornification, however, takes place in the uppermost layer of the SG (SG1) [13], which faces the air-liquid interface and does not have TJ $[1,13]$. We have found an altered epidermal differentiation program in LKO mice, which leaves the K1/K10 less cross-linked and desmosomes undegraded in the SC [15]. The intercellular junctional complex comprises TJ, adherens junction (AJ), and desmosome in the order given in an apical-basal direction [183]. The anatomical principle may indicate that LKO mice have delayed maturation of the junctional complex.

Skin DCs survey the interstitial space and capture antigens derived from self [26] or non-self [27] through TJ protein expression on dendrites [28,29]. Interfollicular epidermal 
keratinocytes anchor Langerhans cells (LCs) through $\alpha_{V} \beta_{6}$ integrin [184], which regulates the activation of transforming growth factor-beta 1 (TGF- $\beta$ [185]. TGF- $\beta$ presents in a pro (pro TGF- $\beta 1$ ) form in the extracellular matrix, and a free, biologically active TGF- $\beta 1$ monomer is hidden among the disulfide cross-linked "bowtie" or "straight jacket" domains [185]. Although enhanced antigen priming is a hallmark feature of impaired barrier function, LKO mice exhibited a weak CHS response (unpublished observations). Therefore, we deem that altered epidermal structure caused by the absence of LOR attenuates the immune effector functions (Figure 2). Hence, we could argue that atopy is a unique class of host defense that is allowed to reside in the epidermal tissue. By extension, the structure of the epidermal tissue may be a primary determinant of immune responses that take place on the body surface; LKO mice were resistant in an experimental S. aureus colonization model [186]. The "immature" structure of the superficial epidermis may affect the LCs' behavioral responses evoked by local pathological stimuli [187]. Further investigations are required, and revealing the mechanism may provide us with novel therapeutic interventions that percutaneously control immune-mediated diseases, such as MS [188,189] or food allergy [190,191], instead of vaccinating against plagues [192].

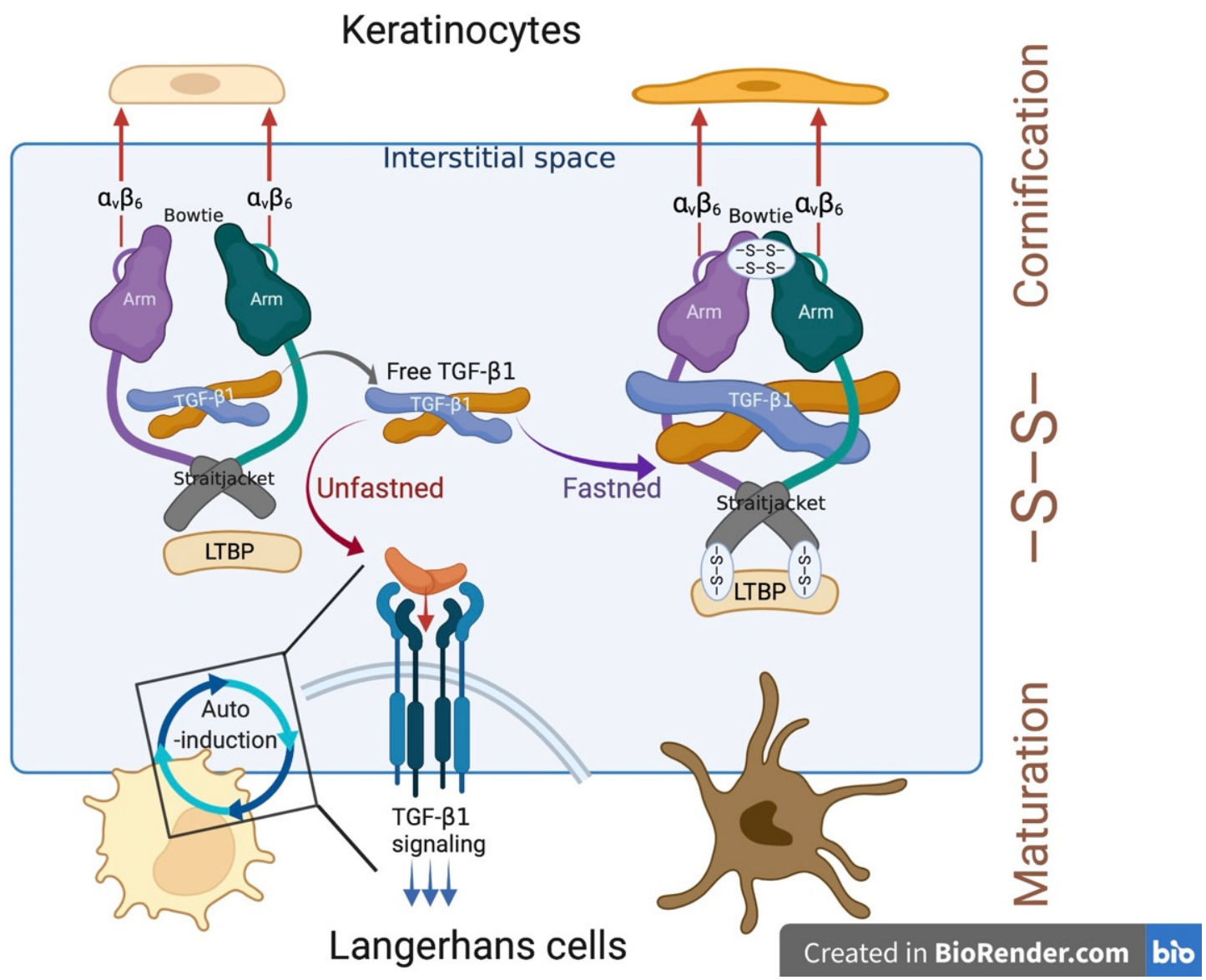

Figure 2. We hypothesized a "Structural imprinting" of the cutaneous immune effector functions. Keratinocytes and Langerhans cells (LCs) might crosstalk via reduction and oxidation [thiol (-SH) and disulfide (-S-S-)] status in the epidermis. Keratinocyte tether LCs via $\alpha_{\mathrm{v}} \beta_{6}$ integrin. Epidermal retention of LCs requires the cell-autonomous transform growth factor-beta 1 (TGF- $\beta 1$ ) signaling. The prodomain (proTGF- $\beta$ "fastens" free TGF- $\beta$ via disulfide cross-linkages in the bowtie and straitjacket regions. The arm domain anchors keratinocytes via $\alpha_{v} \beta_{6}$ integrin and negatively regulates the biological activity of TGF- $\beta$ in the extracellular matrix. Successful cornification involves disulfide cross-linkages of the junctional component, thus possibly permanently inactivating TGF- $\beta$ and promoting LC maturation. 
Author Contributions: Conceptualization, Y.I.; validation, D.R.R.; writing-original draft preparation, Y.I.; review and editing, D.R.R.; supervision, D.R.R. All authors have read and agreed to the published version of the manuscript.

Funding: This research was supported in part by the following grants: JSPS KAKENHI Grant, Grant-in-Aid for Research Activity Start-up (16H06663 to YI), and Early-Career Scientists (18K16018 to YI).

Conflicts of Interest: The authors declare no conflict of interest. The funders had no role in the design of the study; in the collection, analyses, or interpretation of data; in the writing of the manuscript, or in the decision to publish the results.

\section{Abbreviations}

\begin{tabular}{|c|c|}
\hline AD, ATOD & atopic dermatitis \\
\hline CARD14 & caspase recruitment domain family member 14 \\
\hline CDSN & corneosesmosin \\
\hline $\mathrm{CE}$ & cornified cell envelope \\
\hline CHS & contact hypersensitivity \\
\hline CLDN1 & claudin-1 \\
\hline DAMP & damage-associated molecular pattern \\
\hline DC & dendritic cells \\
\hline DMF & dimethyl fumarate \\
\hline DSG & desmoglein \\
\hline EDC & epidermal diffrentiation complex \\
\hline FLG & filaggrin \\
\hline FS & failure to thrive \\
\hline HLA & human leukocyte antigen \\
\hline IL36RN & interleukin-36 receptor antagonist protein \\
\hline IMQ & imiquimod \\
\hline IVL & involucrin \\
\hline KEAP1 & $\begin{array}{l}\text { Kelch-like erythroid cell-derived protein with the cap 'n' collar homology-associated } \\
\text { protein } 1 \text { /NFE2-related factor } 2\end{array}$ \\
\hline KLK & kallikrein \\
\hline LC & Langerhans cell \\
\hline LCE & late cornified cell envelope protein \\
\hline LEKTI & lymphoepithelial Kazal-type related inhibitor type 5 \\
\hline LG & lamellar granule \\
\hline LOF & loss-of-function \\
\hline LOR & loricrin \\
\hline MHC & major histocompatibility complex \\
\hline MS & multiple sclerosis \\
\hline NRF2 & NFE2-related factor 2 \\
\hline NS & Netherton syndrome \\
\hline OMIM & Online Mendelian Inheritance in Man \\
\hline PSORS & psoriasis susceptibility \\
\hline PSS & peeling skin syndrome \\
\hline redox & reduction and oxidation \\
\hline ROR-g & retinoic acid-receptor-related orphan receptor gamma \\
\hline S. aureus & Staphylococcus aureus \\
\hline $\mathrm{SC}$ & stratum corneum \\
\hline SG & stratum granulosum \\
\hline SPINK5 & serine protease inhibitor of Kasal-type 5 \\
\hline SPRR & small prorine-rich protein \\
\hline TGF-b1 & transforming growth factor-beta 1 \\
\hline $\mathrm{T}_{\mathrm{H}}$ & T helper \\
\hline TMEM79 & transmembrane protein 79 \\
\hline TSLP & thymic stromal lymphopoietin \\
\hline UV & ultraviolet \\
\hline
\end{tabular}




\section{References}

1. Eckhart, L.; Lippens, S.; Tschachler, E.; Declercq, W. Cell death by cornification. Biochim. Biophys. Acta 2013, 1833, 3471-3480. [CrossRef] [PubMed]

2. Ishitsuka, Y.; Roop, D.R. Loricrin: Past, Present, and Future. Int. J. Mol. Sci. 2020, 21, 2271. [CrossRef] [PubMed]

3. Rice, R.H.; Green, H. The cornified envelope of terminally differentiated human epidermal keratinocytes consists of cross-linked protein. Cell 1977, 11, 417-422. [CrossRef]

4. Doran, T.I.; Vidrich, A.; Sun, T.T. Intrinsic and extrinsic regulation of the differentiation of skin, corneal and esophageal epithelial cells. Cell 1980, 22, 17-25. [CrossRef]

5. $\quad$ Stark, H.J.; Baur, M.; Breitkreutz, D.; Mirancea, N.; Fusenig, N.E. Organotypic keratinocyte cocultures in defined medium with regular epidermal morphogenesis and differentiation. J. Invest. Dermatol. 1999, 112, 681-691. [CrossRef] [PubMed]

6. Gonzales, K.A.U.; Fuchs, E. Skin and Its Regenerative Powers: An Alliance between Stem Cells and Their Niche. Dev. Cell 2017, 43, 387-401. [CrossRef] [PubMed]

7. Rompolas, P.; Mesa, K.R.; Kawaguchi, K.; Park, S.; Gonzalez, D.; Brown, S.; Boucher, J.; Klein, A.M.; Greco, V. Spatiotemporal coordination of stem cell commitment during epidermal homeostasis. Science 2016, 352, 1471-1474. [CrossRef]

8. Menon, G.K.; Grayson, S.; Elias, P.M. Ionic calcium reservoirs in mammalian epidermis: Ultrastructural localization by ion-capture cytochemistry. J. Invest. Dermatol. 1985, 84, 508-512. [CrossRef]

9. Xie, Z.; Komuves, L.; Yu, Q.C.; Elalieh, H.; Ng, D.C.; Leary, C.; Chang, S.; Crumrine, D.; Yoshizawa, T.; Kato, S.; et al. Lack of the vitamin $\mathrm{D}$ receptor is associated with reduced epidermal differentiation and hair follicle growth. J. Invest. Dermatol. 2002, 118, 11-16. [CrossRef]

10. Saitou, M.; Sugai, S.; Tanaka, T.; Shimouchi, K.; Fuchs, E.; Narumiya, S.; Kakizuka, A. Inhibition of skin development by targeted expression of a dominant-negative retinoic acid receptor. Nature 1995, 374, 159-162. [CrossRef]

11. Imakado, S.; Bickenbach, J.R.; Bundman, D.S.; Rothnagel, J.A.; Attar, P.S.; Wang, X.J.; Walczak, V.R.; Wisniewski, S.; Pote, J.; Gordon, J.S.; et al. Targeting expression of a dominant-negative retinoic acid receptor mutant in the epidermis of transgenic mice results in loss of barrier function. Genes Dev. 1995, 9, 317-329. [CrossRef]

12. Matsui, T.; Kadono-Maekubo, N.; Suzuki, Y.; Furuichi, Y.; Shiraga, K.; Sasaki, H.; Ishida, A.; Takahashi, S.; Okada, T.; Toyooka, K.; et al. A unique mode of keratinocyte death requires intracellular acidification. Proc. Natl. Acad. Sci. USA 2021, 118. [CrossRef]

13. Matsui, T.; Amagai, M. Dissecting the formation, structure and barrier function of the stratum corneum. Int. Immunol. 2015, 27, 269-280. [CrossRef]

14. Kalinin, A.; Marekov, L.N.; Steinert, P.M. Assembly of the epidermal cornified cell envelope. J. Cell Sci. 2001, 114, 3069-3070. [CrossRef] [PubMed]

15. Ishitsuka, Y.; Ogawa, T.; Nakamura, Y.; Kubota, N.; Fujisawa, Y.; Watanabe, R.; Okiyama, N.; Fujimoto, M.; Roop, D.R.; Ishida-Yamamoto, A. Loricrin and NRF2 Coordinate Cornification. JID Innov. 2022, 2, 100065. [CrossRef]

16. Matsuki, M.; Yamashita, F.; Ishida-Yamamoto, A.; Yamada, K.; Kinoshita, C.; Fushiki, S.; Ueda, E.; Morishima, Y.; Tabata, K.; Yasuno, H.; et al. Defective stratum corneum and early neonatal death in mice lacking the gene for transglutaminase 1 (keratinocyte transglutaminase). Proc. Natl. Acad. Sci. USA 1998, 95, 1044-1049. [CrossRef] [PubMed]

17. Sevilla, L.M.; Nachat, R.; Groot, K.R.; Klement, J.F.; Uitto, J.; Djian, P.; Maatta, A.; Watt, F.M. Mice deficient in involucrin, envoplakin, and periplakin have a defective epidermal barrier. J. Cell Biol. 2007, 179, 1599-1612. [CrossRef]

18. Gallicano, G.I.; Kouklis, P.; Bauer, C.; Yin, M.; Vasioukhin, V.; Degenstein, L.; Fuchs, E. Desmoplakin is required early in development for assembly of desmosomes and cytoskeletal linkage. J. Cell Biol. 1998, 143, 2009-2022. [CrossRef]

19. Kugelmann, D.; Radeva, M.Y.; Spindler, V.; Waschke, J. Desmoglein 1 Deficiency Causes Lethal Skin Blistering. J. Invest. Dermatol. 2019, 139, 1596-1599. [CrossRef] [PubMed]

20. Godsel, L.M.; Roth-Carter, Q.R.; Koetsier, J.L.; Tsoi, L.C.; Huffine, A.L.; Broussard, J.A.; Fitz, G.N.; Lloyd, S.M.; Kweon, J.; Burks, H.E.; et al. Translational implications of Th17-skewed inflammation due to genetic deficiency of a cadherin stress sensor. J. Clin. Invest. 2021. [CrossRef] [PubMed]

21. McAleer, M.A.; Pohler, E.; Smith, F.J.; Wilson, N.J.; Cole, C.; MacGowan, S.; Koetsier, J.L.; Godsel, L.M.; Harmon, R.M.; Gruber, R.; et al. Severe dermatitis, multiple allergies, and metabolic wasting syndrome caused by a novel mutation in the N-terminal plakin domain of desmoplakin. J. Allergy Clin. Immunol. 2015, 136, 1268-1276. [CrossRef]

22. Samuelov, L.; Sarig, O.; Harmon, R.M.; Rapaport, D.; Ishida-Yamamoto, A.; Isakov, O.; Koetsier, J.L.; Gat, A.; Goldberg, I.; Bergman, R.; et al. Desmoglein 1 deficiency results in severe dermatitis, multiple allergies and metabolic wasting. Nat. Genet. 2013, 45, 1244-1248. [CrossRef]

23. Huber, M.; Rettler, I.; Bernasconi, K.; Frenk, E.; Lavrijsen, S.P.; Ponec, M.; Bon, A.; Lautenschlager, S.; Schorderet, D.F.; Hohl, D. Mutations of keratinocyte transglutaminase in lamellar ichthyosis. Science 1995, 267, 525-528. [CrossRef]

24. Ishida-Yamamoto, A.; Igawa, S.; Kishibe, M. Molecular basis of the skin barrier structures revealed by electron microscopy. Exp. Dermatol. 2018, 27, 841-846. [CrossRef] [PubMed]

25. Skabytska, Y.; Wolbing, F.; Gunther, C.; Koberle, M.; Kaesler, S.; Chen, K.M.; Guenova, E.; Demircioglu, D.; Kempf, W.E.; Volz, T.; et al. Cutaneous innate immune sensing of Toll-like receptor 2-6 ligands suppresses $\mathrm{T}$ cell immunity by inducing myeloid-derived suppressor cells. Immunity 2014, 41, 762-775. [CrossRef] [PubMed] 
26. Hemmi, H.; Yoshino, M.; Yamazaki, H.; Naito, M.; Iyoda, T.; Omatsu, Y.; Shimoyama, S.; Letterio, J.J.; Nakabayashi, T.; Tagaya, H.; et al. Skin antigens in the steady state are trafficked to regional lymph nodes by transforming growth factor-beta1-dependent cells. Int. Immunol. 2001, 13, 695-704. [CrossRef]

27. Kubo, A.; Nagao, K.; Yokouchi, M.; Sasaki, H.; Amagai, M. External antigen uptake by Langerhans cells with reorganization of epidermal tight junction barriers. J. Exp. Med. 2009, 206, 2937-2946. [CrossRef]

28. Farache, J.; Koren, I.; Milo, I.; Gurevich, I.; Kim, K.W.; Zigmond, E.; Furtado, G.C.; Lira, S.A.; Shakhar, G. Luminal bacteria recruit CD103+ dendritic cells into the intestinal epithelium to sample bacterial antigens for presentation. Immunity 2013, 38, 581-595. [CrossRef] [PubMed]

29. Rescigno, M.; Urbano, M.; Valzasina, B.; Francolini, M.; Rotta, G.; Bonasio, R.; Granucci, F.; Kraehenbuhl, J.P.; Ricciardi-Castagnoli, P. Dendritic cells express tight junction proteins and penetrate gut epithelial monolayers to sample bacteria. Nat. Immunol. 2001, 2, 361-367. [CrossRef]

30. Palmer, C.N.; Irvine, A.D.; Terron-Kwiatkowski, A.; Zhao, Y.; Liao, H.; Lee, S.P.; Goudie, D.R.; Sandilands, A.; Campbell, L.E.; Smith, F.J.; et al. Common loss-of-function variants of the epidermal barrier protein filaggrin are a major predisposing factor for atopic dermatitis. Nat. Genet. 2006, 38, 441-446. [CrossRef]

31. Smith, F.J.; Irvine, A.D.; Terron-Kwiatkowski, A.; Sandilands, A.; Campbell, L.E.; Zhao, Y.; Liao, H.; Evans, A.T.; Goudie, D.R.; Lewis-Jones, S.; et al. Loss-of-function mutations in the gene encoding filaggrin cause ichthyosis vulgaris. Nat. Genet. 2006, 38, 337-342. [CrossRef]

32. Kawasaki, H.; Nagao, K.; Kubo, A.; Hata, T.; Shimizu, A.; Mizuno, H.; Yamada, T.; Amagai, M. Altered stratum corneum barrier and enhanced percutaneous immune responses in filaggrin-null mice. J. Allergy Clin. Immunol. 2012, 129, 1538-1546.e6. [CrossRef] [PubMed]

33. Moniaga, C.S.; Egawa, G.; Kawasaki, H.; Hara-Chikuma, M.; Honda, T.; Tanizaki, H.; Nakajima, S.; Otsuka, A.; Matsuoka, H.; Kubo, A.; et al. Flaky tail mouse denotes human atopic dermatitis in the steady state and by topical application with Dermatophagoides pteronyssinus extract. Am. J. Pathol. 2010, 176, 2385-2393. [CrossRef]

34. Sasaki, T.; Furusyo, N.; Shiohama, A.; Takeuchi, S.; Nakahara, T.; Uchi, H.; Hirota, T.; Tamari, M.; Shimizu, N.; Ebihara, T. Filaggrin loss-of-function mutations are not a predisposing factor for atopic dermatitis in an Ishigaki Island under subtropical climate. J. Dermatol. Sci. 2014, 76, 10-15. [CrossRef]

35. Spergel, J.M.; Mizoguchi, E.; Brewer, J.P.; Martin, T.R.; Bhan, A.K.; Geha, R.S. Epicutaneous sensitization with protein antigen induces localized allergic dermatitis and hyperresponsiveness to methacholine after single exposure to aerosolized antigen in mice. J. Clin. Invest. 1998, 101, 1614-1622. [CrossRef] [PubMed]

36. Paller, A.S.; Spergel, J.M.; Mina-Osorio, P.; Irvine, A.D. The atopic march and atopic multimorbidity: Many trajectories, many pathways. J. Allergy Clin. Immunol. 2019, 143, 46-55. [CrossRef]

37. Has, C.; Jakob, T.; He, Y.; Kiritsi, D.; Hausser, I.; Bruckner-Tuderman, L. Loss of desmoglein 1 associated with palmoplantar keratoderma, dermatitis and multiple allergies. Br. J. Dermatol. 2015, 172, 257-261. [CrossRef] [PubMed]

38. Holstein, J.; Solimani, F.; Baum, C.; Meier, K.; Pollmann, R.; Didona, D.; Tekath, T.; Dugas, M.; Casadei, N.; Hudemann, C. Immunophenotyping in pemphigus reveals a TH17/TFH17 cell-dominated immune response promoting desmoglein1/3-specific autoantibody production. J. Allergy Clin. Immunol. 2021, 147, 2358-2369. [CrossRef]

39. Ong, P.Y.; Leung, D.Y. Bacterial and Viral Infections in Atopic Dermatitis: A Comprehensive Review. Clin. Rev. Allergy Immunol. 2016, 51, 329-337. [CrossRef] [PubMed]

40. Amagai, M.; Matsuyoshi, N.; Wang, Z.; Andl, C.; Stanley, J. Toxin in bullous impetigo and staphylococcal scalded-skin syndrome targets desmoglein 1. Nat. Med. 2000, 6, 1275-1277. [CrossRef]

41. Ouchi, T.; Kubo, A.; Yokouchi, M.; Adachi, T.; Kobayashi, T.; Kitashima, D.Y.; Fujii, H.; Clausen, B.E.; Koyasu, S.; Amagai, M.; et al Langerhans cell antigen capture through tight junctions confers preemptive immunity in experimental staphylococcal scalded skin syndrome. J. Exp. Med. 2011, 208, 2607-2613. [CrossRef]

42. Nemes, Z.; Steinert, P.M. Bricks and mortar of the epidermal barrier. Exp. Mol. Med. 1999, 31, 5-19. [CrossRef] [PubMed]

43. Kubo, A.; Nagao, K.; Amagai, M. Epidermal barrier dysfunction and cutaneous sensitization in atopic diseases. J. Clin. Investig. 2012, 122, 440-447. [CrossRef] [PubMed]

44. Van Scott, E.; Flesch, P. Sulfhydryl and disulfide in keratinization. Science 1954, 119, 70-71. [CrossRef]

45. Ishitsuka, Y.; Roop, D.R. Loricrin Confers Photoprotective Function against UVB in Corneocytes. J. Invest. Dermatol. 2018, 138, 2684-2687. [CrossRef] [PubMed]

46. Schafer, M.; Dutsch, S.; auf dem Keller, U.; Navid, F.; Schwarz, A.; Johnson, D.A.; Johnson, J.A.; Werner, S. Nrf2 establishes a glutathione-mediated gradient of UVB cytoprotection in the epidermis. Genes Dev. 2010, 24, 1045-1058. [CrossRef]

47. Kawachi, Y.; Xu, X.; Taguchi, S.; Sakurai, H.; Nakamura, Y.; Ishii, Y.; Fujisawa, Y.; Furuta, J.; Takahashi, T.; Itoh, K.; et al. Attenuation of UVB-induced sunburn reaction and oxidative DNA damage with no alterations in UVB-induced skin carcinogenesis in Nrf2 gene-deficient mice. J. Invest. Dermatol. 2008, 128, 1773-1779. [CrossRef] [PubMed]

48. Ogawa, T.; Ishitsuka, Y.; Nakamura, Y.; Kubota, N.; Saito, A.; Fujisawa, Y.; Watanabe, R.; Okiyama, N.; Suga, Y.; Roop, D.R.; et al. NRF2 Augments Epidermal Antioxidant Defenses and Promotes Atopy. J Immunol 2020, 205, 907-914. [CrossRef]

49. Kim, H.J.; Barajas, B.; Wang, M.; Nel, A.E. Nrf2 activation by sulforaphane restores the age-related decrease of T(H)1 immunity: Role of dendritic cells. J. Allergy Clin. Immunol. 2008, 121, 1255-1261.e7. [CrossRef] 
50. Ramos-Gomez, M.; Kwak, M.K.; Dolan, P.M.; Itoh, K.; Yamamoto, M.; Talalay, P.; Kensler, T.W. Sensitivity to carcinogenesis is increased and chemoprotective efficacy of enzyme inducers is lost in nrf2 transcription factor-deficient mice. Proc. Natl. Acad. Sci. USA 2001, 98, 3410-3415. [CrossRef]

51. Bern, H.A.; Harkness, D.R.; Blair, S.M. Radioautographic Studies of Keratin Formation. Proc. Natl. Acad. Sci. USA 1955, 41, 55-60. [CrossRef]

52. Rangasamy, T.; Guo, J.; Mitzner, W.A.; Roman, J.; Singh, A.; Fryer, A.D.; Yamamoto, M.; Kensler, T.W.; Tuder, R.M.; Georas, S.N. Disruption of Nrf2 enhances susceptibility to severe airway inflammation and asthma in mice. J. Exp. Med. 2005, 202, 47-59. [CrossRef] [PubMed]

53. Morgan, L.E.; Jaramillo, A.M.; Shenoy, S.K.; Raclawska, D.; Emezienna, N.A.; Richardson, V.L.; Hara, N.; Harder, A.Q.; NeeDell, J.C.; Hennessy, C.E.; et al. Disulfide disruption reverses mucus dysfunction in allergic airway disease. Nat. Commun. 2021, 12, 249. [CrossRef]

54. Ijssennagger, N.; van der Meer, R.; van Mil, S.W.C. Sulfide as a Mucus Barrier-Breaker in Inflammatory Bowel Disease? Trends Mol. Med. 2016, 22, 190-199. [CrossRef] [PubMed]

55. Nguyen, L.H.; Cao, Y.; Hur, J.; Mehta, R.S.; Sikavi, D.R.; Wang, Y.; Ma, W.; Wu, K.; Song, M.; Giovannucci, E.L.; et al. The Sulfur Microbial Diet Is Associated With Increased Risk of Early-Onset Colorectal Cancer Precursors. Gastroenterology 2021, 161, 1423-1432.e4. [CrossRef]

56. Mehrel, T.; Hohl, D.; Rothnagel, J.A.; Longley, M.A.; Bundman, D.; Cheng, C.; Lichti, U.; Bisher, M.E.; Steven, A.C.; Steinert, P.M.; et al. Identification of a major keratinocyte cell envelope protein, loricrin. Cell 1990, 61, 1103-1112. [CrossRef]

57. Huebner, A.J.; Dai, D.; Morasso, M.; Schmidt, E.E.; Schafer, M.; Werner, S.; Roop, D.R. Amniotic fluid activates the nrf2/keap1 pathway to repair an epidermal barrier defect in utero. Dev. Cell 2012, 23, 1238-1246. [CrossRef]

58. Koch, P.J.; de Viragh, P.A.; Scharer, E.; Bundman, D.; Longley, M.A.; Bickenbach, J.; Kawachi, Y.; Suga, Y.; Zhou, Z.; Huber, M.; et al. Lessons from loricrin-deficient mice: Compensatory mechanisms maintaining skin barrier function in the absence of a major cornified envelope protein. J. Cell Biol. 2000, 151, 389-400. [CrossRef] [PubMed]

59. Yamamoto, M.; Kensler, T.W.; Motohashi, H. The KEAP1-NRF2 System: A Thiol-Based Sensor-Effector Apparatus for Maintaining Redox Homeostasis. Physiol Rev 2018, 98, 1169-1203. [CrossRef]

60. Ishitsuka, Y.; Ogawa, T.; Roop, D. The KEAP1/NRF2 Signaling Pathway in Keratinization. Antioxidants 2020, 9, 751. [CrossRef]

61. Ishitsuka, Y.; Huebner, A.J.; Rice, R.H.; Koch, P.J.; Speransky, V.V.; Steven, A.C.; Roop, D.R. Lce1 Family Members Are Nrf2-Target Genes that Are Induced to Compensate for the Loss of Loricrin. J. Invest. Dermatol. 2016, 136, 1656-1663. [CrossRef] [PubMed]

62. Goodwin, Z.A.; de Guzman Strong, C. Recent Positive Selection in Genes of the Mammalian Epidermal Differentiation Complex Locus. Front. Genet. 2016, 7, 227. [CrossRef]

63. Ogawa, T.; Ishitsuka, Y.; Inoue, S.; Nakamura, Y.; Saito, A.; Okiyama, N.; Fujisawa, Y.; Furuta, J.I.; Watanabe, R.; Fujimoto, M Nuclear factor erythroid 2-related factor 2 (Nrf2) regulates epidermal keratinization under psoriatic skin inflammation. Am. J. Pathol. 2020. [CrossRef]

64. Baurecht, H.; Hotze, M.; Brand, S.; Buning, C.; Cormican, P.; Corvin, A.; Ellinghaus, D.; Ellinghaus, E.; Esparza-Gordillo, J.; Folster-Holst, R.; et al. Genome-wide comparative analysis of atopic dermatitis and psoriasis gives insight into opposing genetic mechanisms. Am. J. Hum. Genet. 2015, 96, 104-120. [CrossRef]

65. He, H.; Bissonnette, R.; Wu, J.; Diaz, A.; Proulx, E.S.-C.; Maari, C.; Jack, C.; Louis, M.; Estrada, Y.; Krueger, J.G. Tape strips detect distinct immune and barrier profiles in atopic dermatitis and psoriasis. J. Allergy Clin. Immunol. 2021, 147, 199-212. [CrossRef]

66. Ishitsuka, Y.; Roop, D.R.; Ogawa, T. "Structural imprinting" of the cutaneous immune effector function. Tissue Barriers 2020. [CrossRef]

67. Armstrong, A.W.; Read, C. Pathophysiology, Clinical Presentation, and Treatment of Psoriasis: A Review. JAMA 2020, 323, 1945-1960. [CrossRef] [PubMed]

68. Hamosh, A.; Scott, A.F.; Amberger, J.S.; Bocchini, C.A.; McKusick, V.A. Online Mendelian Inheritance in Man (OMIM), a knowledgebase of human genes and genetic disorders. Nucleic Acids Res. 2005, 33, D514-D517. [CrossRef]

69. Ghoreschi, K.; Balato, A.; Enerback, C.; Sabat, R. Therapeutics targeting the IL-23 and IL-17 pathway in psoriasis. Lancet 2021, 397, 754-766. [CrossRef]

70. McKenzie, B.S.; Kastelein, R.A.; Cua, D.J. Understanding the IL-23-IL-17 immune pathway. Trends Immunol. 2006, 27, 17-23. [CrossRef]

71. Pinkus, H.; Mehregan, A.H. The primary histologic lesion of seborrheic dermatitis and psoriasis. J. Invest. Dermatol. 1966, 46, 109-116. [CrossRef]

72. McGonagle, D.; McDermott, M.F. A proposed classification of the immunological diseases. PLoS Med. 2006, 3, e297. [CrossRef] [PubMed]

73. Szekanecz, Z.; McInnes, I.B.; Schett, G.; Szamosi, S.; Benko, S.; Szucs, G. Autoinflammation and autoimmunity across rheumatic and musculoskeletal diseases. Nat. Rev. Rheumatol. 2021, 17, 585-595. [CrossRef]

74. Kurihara, K.; Fujiyama, T.; Phadungsaksawasdi, P.; Ito, T.; Tokura, Y. Significance of IL-17A-producing CD8+ CD103+ skin resident memory $\mathrm{T}$ cells in psoriasis lesion and their possible relationship to clinical course. J. Dermatol. Sci. 2019, 95, 21-27. [CrossRef] [PubMed]

75. Yamamoto, T. Psoriasis and connective tissue diseases. Int. J. Mol. Sci. 2020, 21, 5803. [CrossRef] 
76. Hammer, R.E.; Maika, S.D.; Richardson, J.A.; Tang, J.P.; Taurog, J.D. Spontaneous inflammatory disease in transgenic rats expressing HLA-B27 and human beta 2m: An animal model of HLA-B27-associated human disorders. Cell 1990, 63, 1099-1112. [CrossRef]

77. Kunstfeld, R.; Hirakawa, S.; Hong, Y.K.; Schacht, V.; Lange-Asschenfeldt, B.; Velasco, P.; Lin, C.; Fiebiger, E.; Wei, X.; Wu, Y.; et al. Induction of cutaneous delayed-type hypersensitivity reactions in VEGF-A transgenic mice results in chronic skin inflammation associated with persistent lymphatic hyperplasia. Blood 2004, 104, 1048-1057. [CrossRef] [PubMed]

78. Sano, S.; Chan, K.S.; Carbajal, S.; Clifford, J.; Peavey, M.; Kiguchi, K.; Itami, S.; Nickoloff, B.J.; DiGiovanni, J. Stat3 links activated keratinocytes and immunocytes required for development of psoriasis in a novel transgenic mouse model. Nat. Med. 2005, 11, 43-49. [CrossRef] [PubMed]

79. Tortola, L.; Rosenwald, E.; Abel, B.; Blumberg, H.; Schäfer, M.; Coyle, A.J.; Renauld, J.-C.; Werner, S.; Kisielow, J.; Kopf, M. Psoriasiform dermatitis is driven by IL-36-mediated DC-keratinocyte crosstalk. J. Clin. Invest. 2012, 122, 3965-3976. [CrossRef]

80. Shepherd, J.; Little, M.C.; Nicklin, M.J. Psoriasis-like cutaneous inflammation in mice lacking interleukin-1 receptor antagonist. J. Invest. Dermatol. 2004, 122, 665-669. [CrossRef]

81. Boyman, O.; Hefti, H.P.; Conrad, C.; Nickoloff, B.J.; Suter, M.; Nestle, F.O. Spontaneous development of psoriasis in a new animal model shows an essential role for resident T cells and tumor necrosis factor-alpha. J. Exp. Med. 2004, 199, 731-736. [CrossRef] [PubMed]

82. van der Fits, L.; Mourits, S.; Voerman, J.S.; Kant, M.; Boon, L.; Laman, J.D.; Cornelissen, F.; Mus, A.M.; Florencia, E.; Prens, E.P.; et al. Imiquimod-induced psoriasis-like skin inflammation in mice is mediated via the IL-23/IL-17 axis. J. Immunol. 2009, 182, 5836-5845. [CrossRef]

83. Kemeny, L. The golden ages of inflammatory skin diseases: Skyrocketing developments in the therapy of psoriasis and atopic dermatitis. J. Eur. Acad. Dermatol. Venereol. 2021, 35, 2239-2240. [CrossRef] [PubMed]

84. Overbeck, T.R.; Griesinger, F. Two cases of psoriasis responding to erlotinib: Time to revisiting inhibition of epidermal growth factor receptor in psoriasis therapy? Dermatology 2012, 225, 179-182. [CrossRef]

85. Cheuk, S.; Schlums, H.; Gallais Serezal, I.; Martini, E.; Chiang, S.C.; Marquardt, N.; Gibbs, A.; Detlofsson, E.; Introini, A.; Forkel, M.; et al. CD49a Expression Defines Tissue-Resident CD8(+) T Cells Poised for Cytotoxic Function in Human Skin. Immunity 2017, 46, 287-300. [CrossRef] [PubMed]

86. Vo, S.; Watanabe, R.; Koguchi-Yoshioka, H.; Matsumura, Y.; Ishitsuka, Y.; Nakamura, Y.; Okiyama, N.; Fujisawa, Y.; Fujimoto, M. CD8 resident memory $\mathrm{T}$ cells with interleukin 17A-producing potential are accumulated in disease-naïve nonlesional sites of psoriasis possibly in correlation with disease duration. Br. J. Dermatol. 2019, 181, 410-412. [CrossRef]

87. Morimoto, S.; Yoshikawa, K.; Kozuka, T.; Kitano, Y.; Imanaka, S.; Fukuo, K.; Koh, E.; Kumahara, Y. An open study of vitamin D3 treatment in psoriasis vulgaris. Br. J. Dermatol. 1986, 115, 421-429. [CrossRef]

88. Fujiyama, T.; Ito, T.; Umayahara, T.; Ikeya, S.; Tatsuno, K.; Funakoshi, A.; Hashizume, H.; Tokura, Y. Topical application of a vitamin D3 analogue and corticosteroid to psoriasis plaques decreases skin infiltration of TH17 cells and their ex vivo expansion. J. Allergy Clin. Immunol. 2016, 138, 517-528. [CrossRef]

89. Hashimoto, K.; Matsumoto, K.; Higashiyama, M.; Nishida, Y.; Yoshikawa, K. Growth-inhibitory effects of 1,25-dihydroxyvitamin D3 on normal and psoriatic keratinocytes. Br. J. Dermatol. 1990, 123, 93-98. [CrossRef]

90. Takahashi, H.; Ibe, M.; Kinouchi, M.; Ishida-Yamamoto, A.; Hashimoto, Y.; Iizuka, H. Similarly potent action of 1,25dihydroxyvitamin D3 and its analogues, tacalcitol, calcipotriol, and maxacalcitol on normal human keratinocyte proliferation and differentiation. J. Dermatol. Sci. 2003, 31, 21-28. [CrossRef]

91. Mischke, D.; Korge, B.P.; Marenholz, I.; Volz, A.; Ziegler, A. Genes encoding structural proteins of epidermal cornification and S100 calcium-binding proteins form a gene complex ("epidermal differentiation complex") on human chromosome 1q21. J. Invest. Dermatol. 1996, 106, 989-992. [CrossRef]

92. Backendorf, C.; Hohl, D. A common origin for cornified envelope proteins? Nat. Genet. 1992, 2, 91. [CrossRef]

93. de Cid, R.; Riveira-Munoz, E.; Zeeuwen, P.L.; Robarge, J.; Liao, W.; Dannhauser, E.N.; Giardina, E.; Stuart, P.E.; Nair, R.; Helms, C.; et al. Deletion of the late cornified envelope LCE3B and LCE3C genes as a susceptibility factor for psoriasis. Nat. Genet. 2009, 41, 211-215. [CrossRef] [PubMed]

94. Giardina, E.; Capon, F.; De Rosa, M.C.; Mango, R.; Zambruno, G.; Orecchia, A.; Chimenti, S.; Giardina, B.; Novelli, G. Characterization of the loricrin (LOR) gene as a positional candidate for the PSORS4 psoriasis susceptibility locus. Ann. Hum. Genet. 2004, 68, 639-645. [CrossRef]

95. Zhao, Y.; Terron-Kwiatkowski, A.; Liao, H.; Lee, S.P.; Allen, M.H.; Hull, P.R.; Campbell, L.E.; Trembath, R.C.; Capon, F.; Griffiths, C.E.; et al. Filaggrin null alleles are not associated with psoriasis. J. Invest. Dermatol. 2007, 127, 1878-1882. [CrossRef]

96. Archer, N.K.; Dilolli, M.N.; Miller, L.S. Pushing the envelope in psoriasis: Late cornified envelope proteins possess antimicrobial activity. J. Invest. Dermatol. 2017, 137, 2257-2259. [CrossRef]

97. Jarnik, M.; de Viragh, P.A.; Scharer, E.; Bundman, D.; Simon, M.N.; Roop, D.R.; Steven, A.C. Quasi-normal cornified cell envelopes in loricrin knockout mice imply the existence of a loricrin backup system. J. Invest. Dermatol. 2002, 118, 102-109. [CrossRef]

98. Bergboer, J.G.; Tjabringa, G.S.; Kamsteeg, M.; van Vlijmen-Willems, I.M.; Rodijk-Olthuis, D.; Jansen, P.A.; Thuret, J.Y.; Narita, M.; Ishida-Yamamoto, A.; Zeeuwen, P.L.; et al. Psoriasis risk genes of the late cornified envelope-3 group are distinctly expressed compared with genes of other LCE groups. Am. J. Pathol. 2011, 178, 1470-1477. [CrossRef] [PubMed] 
99. Bergboer, J.G.; Oostveen, A.M.; de Jager, M.E.; Zeeuwen, P.L.; Joosten, I.; Seyger, M.M.; Schalkwijk, J. Koebner phenomenon in psoriasis is not associated with deletion of late cornified envelope genes LCE3B and LCE3C. J. Invest. Dermatol. 2012, 132, 475-476. [CrossRef] [PubMed]

100. Niehues, H.; Tsoi, L.C.; van der Krieken, D.A.; Jansen, P.A.M.; Oortveld, M.A.W.; Rodijk-Olthuis, D.; van Vlijmen, I.; Hendriks, W.; Helder, R.W.; Bouwstra, J.A.; et al. Psoriasis-Associated Late Cornified Envelope (LCE) Proteins Have Antibacterial Activity. J. Invest. Dermatol. 2017, 137, 2380-2388. [CrossRef] [PubMed]

101. Mattiuzzo, M.; Bandiera, A.; Gennaro, R.; Benincasa, M.; Pacor, S.; Antcheva, N.; Scocchi, M. Role of the Escherichia coli SbmA in the antimicrobial activity of proline-rich peptides. Mol. Microbiol. 2007, 66, 151-163. [CrossRef] [PubMed]

102. Zhang, C.; Hu, Z.; Lone, A.G.; Artami, M.; Edwards, M.; Stein, M.; Harris-Tryon, T.A. Small proline-rich proteins 1 and 2 function as antimicrobial proteins in the skin. bioRxiv 2021. [CrossRef]

103. McFadden, J.; Baker, B.; Powles, A.; Fry, L. Psoriasis and streptococci: The natural selection of psoriasis revisited. Br. J. Dermatol. 2009, 160, 929-937. [CrossRef] [PubMed]

104. Riveira-Munoz, E.; He, S.-M.; Escaramís, G.; Stuart, P.E.; Hüffmeier, U.; Lee, C.; Kirby, B.; Oka, A.; Giardina, E.; Liao, W. Meta-analysis confirms the LCE3C_LCE3B deletion as a risk factor for psoriasis in several ethnic groups and finds interaction with HLA-Cw6. J. Invest. Dermatol. 2011, 131, 1105-1109. [CrossRef] [PubMed]

105. Moyle, M.; Cevikbas, F.; Harden, J.L.; Guttman-Yassky, E. Understanding the immune landscape in atopic dermatitis: The era of biologics and emerging therapeutic approaches. Exp. Dermatol. 2019, 28, 756-768. [CrossRef]

106. Kobayashi, T.; Motomura, Y.; Moro, K. Discovery of group 2 innate lymphoid cells has changed the concept of type 2 immune diseases. Int. Immunol. 2021. [CrossRef]

107. Gowthaman, U.; Chen, J.S.; Zhang, B.; Flynn, W.F.; Lu, Y.; Song, W.; Joseph, J.; Gertie, J.A.; Xu, L.; Collet, M.A.; et al. Identification of a $\mathrm{T}$ follicular helper cell subset that drives anaphylactic IgE. Science 2019, 365. [CrossRef]

108. Kupper, T.S.; Ballard, D.W.; Chua, A.O.; McGuire, J.S.; Flood, P.M.; Horowitz, M.C.; Langdon, R.; Lightfoot, L.; Gubler, U. Human keratinocytes contain mRNA indistinguishable from monocyte interleukin 1 alpha and beta mRNA. Keratinocyte epidermal cell-derived thymocyte-activating factor is identical to interleukin 1. J. Exp. Med. 1986, 164, 2095-2100. [CrossRef]

109. Schmitz, J.; Owyang, A.; Oldham, E.; Song, Y.; Murphy, E.; McClanahan, T.K.; Zurawski, G.; Moshrefi, M.; Qin, J.; Li, X.; et al IL-33, an interleukin-1-like cytokine that signals via the IL-1 receptor-related protein ST2 and induces T helper type 2-associated cytokines. Immunity 2005, 23, 479-490. [CrossRef]

110. Matzinger, P. The danger model: A renewed sense of self. Science 2002, 296, 301-305. [CrossRef]

111. Gahring, L.C.; Buckley, A.; Daynes, R.A. Presence of epidermal-derived thymocyte activating factor/interleukin 1 in normal human stratum corneum. J. Clin. Invest. 1985, 76, 1585-1591. [CrossRef]

112. Kezic, S.; O’Regan, G.M.; Lutter, R.; Jakasa, I.; Koster, E.S.; Saunders, S.; Caspers, P.; Kemperman, P.M.; Puppels, G.J.; Sandilands, A.; et al. Filaggrin loss-of-function mutations are associated with enhanced expression of IL-1 cytokines in the stratum corneum of patients with atopic dermatitis and in a murine model of filaggrin deficiency. J. Allergy Clin. Immunol. 2012, 129, 1031-1039.e1. [CrossRef]

113. Harding, C.R.; Aho, S.; Bosko, C.A. Filaggrin-Revisited. Int. J. Cosmet. Sci. 2013, 35, 412-423. [CrossRef]

114. Ishida-Yamamoto, A.; Igawa, S.; Kishibe, M. Order and disorder in corneocyte adhesion. J. Dermatol. 2011, 38, 645-654. [CrossRef]

115. Jang, Y.H.; Choi, J.K.; Jin, M.; Choi, Y.-A.; Ryoo, Z.Y.; Lee, H.-S.; Park, P.-H.; Kim, S.-U.; Kwon, T.K.; Jang, M.H. House dust mite increases pro-Th2 cytokines IL-25 and IL-33 via the activation of TLR1/6 signaling. J. Invest. Dermatol. 2017, 137, 2354-2361. [CrossRef] [PubMed]

116. Tordesillas, L.; Goswami, R.; Benede, S.; Grishina, G.; Dunkin, D.; Jarvinen, K.M.; Maleki, S.J.; Sampson, H.A.; Berin, M.C. Skin exposure promotes a Th2-dependent sensitization to peanut allergens. J. Clin. Invest. 2014, 124, 4965-4975. [CrossRef]

117. Al Kindi, A.; Williams, H.; Matsuda, K.; Alkahtani, A.M.; Saville, C.; Bennett, H.; Alshammari, Y.; Tan, S.Y.; O’Neill, C.; Tanaka, A. Staphylococcus aureus second immunoglobulin-binding protein drives atopic dermatitis via IL-33. J. Allergy Clin. Immunol. 2021, 147, 1354-1368.e3. [CrossRef]

118. Moriwaki, M.; Iwamoto, K.; Niitsu, Y.; Matsushima, A.; Yanase, Y.; Hisatsune, J.; Sugai, M.; Hide, M. Staphylococcus aureus from atopic dermatitis skin accumulates in the lysosomes of keratinocytes with induction of IL-1alpha secretion via TLR9. Allergy 2019, 74, 560-571. [CrossRef]

119. Archer, N.K.; Jo, J.H.; Lee, S.K.; Kim, D.; Smith, B.; Ortines, R.V.; Wang, Y.; Marchitto, M.C.; Ravipati, A.; Cai, S.S.; et al. Injury, dysbiosis, and filaggrin deficiency drive skin inflammation through keratinocyte IL-1alpha release. J. Allergy Clin. Immunol. 2019, 143, 1426-1443.e6. [CrossRef] [PubMed]

120. Lee, R.T.; Briggs, W.H.; Cheng, G.C.; Rossiter, H.B.; Libby, P.; Kupper, T. Mechanical deformation promotes secretion of IL-1 alpha and IL-1 receptor antagonist. J. Immunol. 1997, 159, 5084-5088. [PubMed]

121. Sanada, S.; Hakuno, D.; Higgins, L.J.; Schreiter, E.R.; McKenzie, A.N.; Lee, R.T. IL-33 and ST2 comprise a critical biomechanically induced and cardioprotective signaling system. J. Clin. Invest. 2007, 117, 1538-1549. [CrossRef] [PubMed]

122. Leyva-Castillo, J.M.; Galand, C.; Kam, C.; Burton, O.; Gurish, M.; Musser, M.A.; Goldsmith, J.D.; Hait, E.; Nurko, S.; Brombacher, F.; et al. Mechanical Skin Injury Promotes Food Anaphylaxis by Driving Intestinal Mast Cell Expansion. Immunity 2019, 50, 1262-1275.e4. [CrossRef] 
123. Soumelis, V.; Reche, P.A.; Kanzler, H.; Yuan, W.; Edward, G.; Homey, B.; Gilliet, M.; Ho, S.; Antonenko, S.; Lauerma, A.; et al. Human epithelial cells trigger dendritic cell mediated allergic inflammation by producing TSLP. Nat. Immunol. 2002, 3, 673-680. [CrossRef] [PubMed]

124. Nakajima, S.; Igyarto, B.Z.; Honda, T.; Egawa, G.; Otsuka, A.; Hara-Chikuma, M.; Watanabe, N.; Ziegler, S.F.; Tomura, M.; Inaba, K.; et al. Langerhans cells are critical in epicutaneous sensitization with protein antigen via thymic stromal lymphopoietin receptor signaling. J. Allergy Clin. Immunol. 2012, 129, 1048-1055. [CrossRef] [PubMed]

125. Oyoshi, M.K.; Larson, R.P.; Ziegler, S.F.; Geha, R.S. Mechanical injury polarizes skin dendritic cells to elicit a T(H)2 response by inducing cutaneous thymic stromal lymphopoietin expression. J. Allergy Clin. Immunol. 2010, 126, 976-984, 984.e1-5. [CrossRef]

126. Kim, B.S.; Siracusa, M.C.; Saenz, S.A.; Noti, M.; Monticelli, L.A.; Sonnenberg, G.F.; Hepworth, M.R.; Van Voorhees, A.S.; Comeau, M.R.; Artis, D. TSLP elicits IL-33-independent innate lymphoid cell responses to promote skin inflammation. Sci. Transl. Med. 2013, 5, 170ra116. [CrossRef]

127. Wilson, S.R.; The, L.; Batia, L.M.; Beattie, K.; Katibah, G.E.; McClain, S.P.; Pellegrino, M.; Estandian, D.M.; Bautista, D.M. The epithelial cell-derived atopic dermatitis cytokine TSLP activates neurons to induce itch. Cell 2013, 155, 285-295. [CrossRef] [PubMed]

128. Nakajima, S.; Kabata, H.; Kabashima, K.; Asano, K. Anti-TSLP antibodies: Targeting a master regulator of type 2 immune responses. Allergol. Int. 2020, 69, 197-203. [CrossRef] [PubMed]

129. Beck, L.A.; Thaçi, D.; Hamilton, J.D.; Graham, N.M.; Bieber, T.; Rocklin, R.; Ming, J.E.; Ren, H.; Kao, R.; Simpson, E. Dupilumab treatment in adults with moderate-to-severe atopic dermatitis. N. Engl. J. Med. 2014, 371, 130-139. [CrossRef] [PubMed]

130. Guttman-Yassky, E.; Bissonnette, R.; Ungar, B.; Suarez-Farinas, M.; Ardeleanu, M.; Esaki, H.; Suprun, M.; Estrada, Y.; Xu, H.; Peng, X.; et al. Dupilumab progressively improves systemic and cutaneous abnormalities in patients with atopic dermatitis. $J$. Allergy Clin. Immunol. 2019, 143, 155-172. [CrossRef]

131. Kabashima, K.; Matsumura, T.; Komazaki, H.; Kawashima, M. Trial of nemolizumab and topical agents for atopic dermatitis with pruritus. N. Engl. J. Med. 2020, 383, 141-150. [CrossRef] [PubMed]

132. Cartron, A.M.; Nguyen, T.H.; Roh, Y.S.; Kwatra, M.M.; Kwatra, S.G. Janus kinase inhibitors for atopic dermatitis: A promising treatment modality. Clin. Exp. Dermatol. 2021, 46, 820-824. [CrossRef] [PubMed]

133. Kubo, A.; Ishizaki, I.; Kubo, A.; Kawasaki, H.; Nagao, K.; Ohashi, Y.; Amagai, M. The stratum corneum comprises three layers with distinct metal-ion barrier properties. Sci. Rep. 2013, 3, 1731. [CrossRef] [PubMed]

134. Steinert, P.M.; Cantieri, J.S.; Teller, D.C.; Lonsdale-Eccles, J.D.; Dale, B.A. Characterization of a class of cationic proteins that specifically interact with intermediate filaments. Proc. Natl. Acad. Sci. USA 1981, 78, 4097-4101. [CrossRef] [PubMed]

135. Brunner, P.M.; Guttman-Yassky, E. Racial differences in atopic dermatitis. Ann. Allergy Asthma Immunol. 2019, 122, 449-455. [CrossRef]

136. Margolis, D.J.; Gupta, J.; Apter, A.J.; Ganguly, T.; Hoffstad, O.; Papadopoulos, M.; Rebbeck, T.R.; Mitra, N. Filaggrin-2 variation is associated with more persistent atopic dermatitis in African American subjects. J. Allergy Clin. Immunol. 2014, 133, 784-789. [CrossRef]

137. Muhandes, L.; Chapsa, M.; Pippel, M.; Behrendt, R.; Ge, Y.; Dahl, A.; Yi, B.; Dalpke, A.; Winkler, S.; Hiller, M.; et al. Low Threshold for Cutaneous Allergen Sensitization but No Spontaneous Dermatitis or Atopy in FLG-Deficient Mice. J. Invest. Dermatol. 2021, 141, 2611-2619. [CrossRef]

138. Fallon, P.G.; Sasaki, T.; Sandilands, A.; Campbell, L.E.; Saunders, S.P.; Mangan, N.E.; Callanan, J.J.; Kawasaki, H.; Shiohama, A.; Kubo, A.; et al. A homozygous frameshift mutation in the mouse Flg gene facilitates enhanced percutaneous allergen priming. Nat. Genet. 2009, 41, 602-608. [CrossRef]

139. Saunders, S.P.; Moran, T.; Floudas, A.; Wurlod, F.; Kaszlikowska, A.; Salimi, M.; Quinn, E.M.; Oliphant, C.J.; Nunez, G.; McManus, R.; et al. Spontaneous atopic dermatitis is mediated by innate immunity, with the secondary lung inflammation of the atopic march requiring adaptive immunity. J. Allergy Clin. Immunol. 2016, 137, 482-491. [CrossRef]

140. Gruber, R.; Elias, P.M.; Crumrine, D.; Lin, T.K.; Brandner, J.M.; Hachem, J.P.; Presland, R.B.; Fleckman, P.; Janecke, A.R.; Sandilands, A.; et al. Filaggrin genotype in ichthyosis vulgaris predicts abnormalities in epidermal structure and function. Am. J. Pathol. 2011, 178, 2252-2263. [CrossRef]

141. Saunders, S.P.; Goh, C.S.; Brown, S.J.; Palmer, C.N.; Porter, R.M.; Cole, C.; Campbell, L.E.; Gierlinski, M.; Barton, G.J.; Schneider G.; et al. Tmem79/Matt is the matted mouse gene and is a predisposing gene for atopic dermatitis in human subjects. J. Allergy Clin. Immunol. 2013, 132, 1121-1129. [CrossRef] [PubMed]

142. Sasaki, T.; Shiohama, A.; Kubo, A.; Kawasaki, H.; Ishida-Yamamoto, A.; Yamada, T.; Hachiya, T.; Shimizu, A.; Okano, H.; Kudoh, J.; et al. A homozygous nonsense mutation in the gene for Tmem79, a component for the lamellar granule secretory system, produces spontaneous eczema in an experimental model of atopic dermatitis. J. Allergy Clin. Immunol. 2013, 132, 1111-1120. [CrossRef]

143. Emrick, J.J.; Mathur, A.; Wei, J.; Gracheva, E.O.; Gronert, K.; Rosenblum, M.D.; Julius, D. Tissue-specific contributions of Tmem79 to atopic dermatitis and mast cell-mediated histaminergic itch. Proc. Natl. Acad. Sci. USA 2018, 115, E12091-E12100. [CrossRef] [PubMed]

144. Chen, M.; Amado, N.; Tan, J.; Reis, A.; Ge, M.; Abreu, J.G.; He, X. TMEM79/MATTRIN defines a pathway for Frizzled regulation and is required for Xenopus embryogenesis. Elife 2020, 9. [CrossRef] [PubMed] 
145. Simon, M.; Jonca, N.; Guerrin, M.; Haftek, M.; Bernard, D.; Caubet, C.; Egelrud, T.; Schmidt, R.; Serre, G. Refined characterization of corneodesmosin proteolysis during terminal differentiation of human epidermis and its relationship to desquamation. J. Biol. Chem. 2001, 276, 20292-20299. [CrossRef] [PubMed]

146. Hohl, D.; Mehrel, T.; Lichti, U.; Turner, M.L.; Roop, D.R.; Steinert, P.M. Characterization of human loricrin. Structure and function of a new class of epidermal cell envelope proteins. J. Biol. Chem. 1991, 266, 6626-6636. [CrossRef]

147. Serre, G.; Mils, V.; Haftek, M.; Vincent, C.; Croute, F.; Reano, A.; Ouhayoun, J.P.; Bettinger, S.; Soleilhavoup, J.P. Identification of late differentiation antigens of human cornified epithelia, expressed in re-organized desmosomes and bound to cross-linked envelope. J. Invest. Dermatol. 1991, 97, 1061-1072. [CrossRef]

148. Samuelov, L.; Sprecher, E. Peeling off the genetics of atopic dermatitis-like congenital disorders. J. Allergy Clin. Immunol. 2014, 134, 808-815. [CrossRef]

149. Descargues, P.; Deraison, C.; Bonnart, C.; Kreft, M.; Kishibe, M.; Ishida-Yamamoto, A.; Elias, P.; Barrandon, Y.; Zambruno, G.; Sonnenberg, A.; et al. Spink5-deficient mice mimic Netherton syndrome through degradation of desmoglein 1 by epidermal protease hyperactivity. Nat. Genet. 2005, 37, 56-65. [CrossRef]

150. Furio, L.; de Veer, S.; Jaillet, M.; Briot, A.; Robin, A.; Deraison, C.; Hovnanian, A. Transgenic kallikrein 5 mice reproduce major cutaneous and systemic hallmarks of Netherton syndrome. J. Exp. Med. 2014, 211, 499-513. [CrossRef]

151. Leclerc, E.A.; Huchenq, A.; Mattiuzzo, N.R.; Metzger, D.; Chambon, P.; Ghyselinck, N.B.; Serre, G.; Jonca, N.; Guerrin, M. Corneodesmosin gene ablation induces lethal skin-barrier disruption and hair-follicle degeneration related to desmosome dysfunction. J. Cell Sci. 2009, 122, 2699-2709. [CrossRef] [PubMed]

152. Matsumoto, M.; Zhou, Y.; Matsuo, S.; Nakanishi, H.; Hirose, K.; Oura, H.; Arase, S.; Ishida-Yamamoto, A.; Bando, Y.; Izumi, K.; et al. Targeted deletion of the murine corneodesmosin gene delineates its essential role in skin and hair physiology. Proc. Natl. Acad. Sci. USA 2008, 105, 6720-6724. [CrossRef] [PubMed]

153. Doebel, T.; Voisin, B.; Nagao, K. Langerhans Cells-The Macrophage in Dendritic Cell Clothing. Trends Immunol 2017, 38, 817-828. [CrossRef] [PubMed]

154. Noda, S.; Suarez-Farinas, M.; Ungar, B.; Kim, S.J.; de Guzman Strong, C.; Xu, H.; Peng, X.; Estrada, Y.D.; Nakajima, S.; Honda, T.; et al. The Asian atopic dermatitis phenotype combines features of atopic dermatitis and psoriasis with increased TH17 polarization. J. Allergy Clin. Immunol. 2015, 136, 1254-1264. [CrossRef]

155. Esaki, H.; Brunner, P.M.; Renert-Yuval, Y.; Czarnowicki, T.; Huynh, T.; Tran, G.; Lyon, S.; Rodriguez, G.; Immaneni, S.; Johnson, D.B.; et al. Early-onset pediatric atopic dermatitis is TH2 but also TH17 polarized in skin. J. Allergy Clin. Immunol. 2016, 138, 1639-1651. [CrossRef]

156. Hoogendoorn, A.; Avery, T.D.; Li, J.; Bursill, C.; Abell, A.; Grace, P.M. Emerging Therapeutic Applications for Fumarates. Trends Pharmacol. Sci. 2021, 42, 239-254. [CrossRef] [PubMed]

157. Muzumdar, S.; Koch, M.; Hiebert, H.; Bapst, A.; Gravina, A.; Bloch, W.; Beer, H.D.; Werner, S.; Schafer, M. Genetic activation of Nrf2 reduces cutaneous symptoms in a murine model of Netherton syndrome. Dis. Model. Mech. 2020, 13. [CrossRef]

158. Schafer, M.; Farwanah, H.; Willrodt, A.H.; Huebner, A.J.; Sandhoff, K.; Roop, D.; Hohl, D.; Bloch, W.; Werner, S. Nrf2 links epidermal barrier function with antioxidant defense. EMBO Mol. Med. 2012, 4, 364-379. [CrossRef]

159. Wakabayashi, N.; Itoh, K.; Wakabayashi, J.; Motohashi, H.; Noda, S.; Takahashi, S.; Imakado, S.; Kotsuji, T.; Otsuka, F.; Roop, D.R.; et al. Keap1-null mutation leads to postnatal lethality due to constitutive Nrf2 activation. Nat. Genet. 2003, 35, 238-245. [CrossRef]

160. Schafer, M.; Willrodt, A.H.; Kurinna, S.; Link, A.S.; Farwanah, H.; Geusau, A.; Gruber, F.; Sorg, O.; Huebner, A.J.; Roop, D.R.; et al. Activation of Nrf2 in keratinocytes causes chloracne (MADISH)-like skin disease in mice. EMBO Mol. Med. 2014, 6, 442-457. [CrossRef]

161. Pickard, C.; Louafi, F.; McGuire, C.; Lowings, K.; Kumar, P.; Cooper, H.; Dearman, R.J.; Cumberbatch, M.; Kimber, I.; Healy, E.; et al. The cutaneous biochemical redox barrier: A component of the innate immune defenses against sensitization by highly reactive environmental xenobiotics. J. Immunol. 2009, 183, 7576-7584. [CrossRef]

162. Kitagaki, H.; Fujisawa, S.; Watanabe, K.; Hayakawa, K.; Shiohara, T. Immediate-type hypersensitivity response followed by a late reaction is induced by repeated epicutaneous application of contact sensitizing agents in mice. J. Invest. Dermatol. 1995, 105, 749-755. [CrossRef] [PubMed]

163. Dalziel, K.; Dykes, P.J.; Marks, R. Inflammation due to intra-cutaneous implantation of stratum corneum. Br. J. Exp. Pathol. 1984, 65, 107-115. [PubMed]

164. Allen, A.; Siegfried, E.; Silverman, R.; Williams, M.L.; Elias, P.M.; Szabo, S.K.; Korman, N.J. Significant absorption of topical tacrolimus in 3 patients with Netherton syndrome. Arch. Dermatol. 2001, 137, 747-750. [PubMed]

165. O'Shaughnessy, R.F.; Choudhary, I.; Harper, J.I. Interleukin-1 alpha blockade prevents hyperkeratosis in an in vitro model of lamellar ichthyosis. Hum. Mol. Genet. 2010, 19, 2594-2605. [CrossRef]

166. Murphy, J.E.; Morales, R.E.; Scott, J.; Kupper, T.S. IL-1 alpha, innate immunity, and skin carcinogenesis: The effect of constitutive expression of IL-1 alpha in epidermis on chemical carcinogenesis. J. Immunol. 2003, 170, 5697-5703. [CrossRef]

167. auf dem Keller, U.; Huber, M.; Beyer, T.A.; Kumin, A.; Siemes, C.; Braun, S.; Bugnon, P.; Mitropoulos, V.; Johnson, D.A.; Johnson, J.A.; et al. Nrf transcription factors in keratinocytes are essential for skin tumor prevention but not for wound healing. Mol. Cell Biol. 2006, 26, 3773-3784. [CrossRef] 
168. Xu, C.; Huang, M.T.; Shen, G.; Yuan, X.; Lin, W.; Khor, T.O.; Conney, A.H.; Kong, A.N. Inhibition of 7,12-dimethylbenz(a)anthraceneinduced skin tumorigenesis in C57BL/ 6 mice by sulforaphane is mediated by nuclear factor E2-related factor 2. Cancer Res. 2006, 66, 8293-8296. [CrossRef] [PubMed]

169. Herbert, D.R.; Holscher, C.; Mohrs, M.; Arendse, B.; Schwegmann, A.; Radwanska, M.; Leeto, M.; Kirsch, R.; Hall, P.; Mossmann, $\mathrm{H}$;; et al. Alternative macrophage activation is essential for survival during schistosomiasis and downmodulates $\mathrm{T}$ helper 1 responses and immunopathology. Immunity 2004, 20, 623-635. [CrossRef]

170. Dalessandri, T.; Crawford, G.; Hayes, M.; Castro Seoane, R.; Strid, J. IL-13 from intraepithelial lymphocytes regulates tissue homeostasis and protects against carcinogenesis in the skin. Nat. Commun. 2016, 7, 12080. [CrossRef]

171. Strid, J.; Sobolev, O.; Zafirova, B.; Polic, B.; Hayday, A. The intraepithelial T cell response to NKG2D-ligands links lymphoid stress surveillance to atopy. Science 2011, 334, 1293-1297. [CrossRef] [PubMed]

172. Strid, J.; Roberts, S.J.; Filler, R.B.; Lewis, J.M.; Kwong, B.Y.; Schpero, W.; Kaplan, D.H.; Hayday, A.C.; Girardi, M. Acute upregulation of an NKG2D ligand promotes rapid reorganization of a local immune compartment with pleiotropic effects on carcinogenesis. Nat. Immunol. 2008, 9, 146-154. [CrossRef] [PubMed]

173. Magin, T.M. A keaper and a striker maintain epidermal homeostasis. Nat. Genet. 2003, 35, 202-204. [CrossRef] [PubMed]

174. Strasser, B.; Mlitz, V.; Hermann, M.; Rice, R.H.; Eigenheer, R.A.; Alibardi, L.; Tschachler, E.; Eckhart, L. Evolutionary origin and diversification of epidermal barrier proteins in amniotes. Mol. Biol. Evol. 2014, 31, 3194-3205. [CrossRef]

175. Ehrlich, F.; Fischer, H.; Langbein, L.; Praetzel-Wunder, S.; Ebner, B.; Figlak, K.; Weissenbacher, A.; Sipos, W.; Tschachler, E.; Eckhart, L. Differential Evolution of the Epidermal Keratin Cytoskeleton in Terrestrial and Aquatic Mammals. Mol. Biol. Evol. 2019, 36, 328-340. [CrossRef]

176. Simon, M.; Tazi-Ahnini, R.; Jonca, N.; Caubet, C.; Cork, M.J.; Serre, G. Alterations in the desquamation-related proteolytic cleavage of corneodesmosin and other corneodesmosomal proteins in psoriatic lesional epidermis. Br. J. Dermatol. 2008, 159, 77-85. [CrossRef]

177. Allen, M.; Ishida-Yamamoto, A.; McGrath, J.; Davison, S.; Iizuka, H.; Simon, M.; Guerrin, M.; Hayday, A.; Vaughan, R.; Serre, G.; et al. Corneodesmosin expression in psoriasis vulgaris differs from normal skin and other inflammatory skin disorders. Lab Invest. 2001, 81, 969-976. [CrossRef] [PubMed]

178. Rice, R.H.; Durbin-Johnson, B.P.; Ishitsuka, Y.; Salemi, M.; Phinney, B.S.; Rocke, D.M.; Roop, D.R. Proteomic Analysis of Loricrin Knockout Mouse Epidermis. J. Proteome Res. 2016, 15, 2560-2566. [CrossRef] [PubMed]

179. Suga, Y.; Jarnik, M.; Attar, P.S.; Longley, M.A.; Bundman, D.; Steven, A.C.; Koch, P.J.; Roop, D.R. Transgenic mice expressing a mutant form of loricrin reveal the molecular basis of the skin diseases, Vohwinkel syndrome and progressive symmetric erythrokeratoderma. J. Cell Biol. 2000, 151, 401-412. [CrossRef] [PubMed]

180. Hadj-Rabia, S.; Baala, L.; Vabres, P.; Hamel-Teillac, D.; Jacquemin, E.; Fabre, M.; Lyonnet, S.; De Prost, Y.; Munnich, A.; Hadchouel, M.; et al. Claudin-1 gene mutations in neonatal sclerosing cholangitis associated with ichthyosis: A tight junction disease. Gastroenterology 2004, 127, 1386-1390. [CrossRef]

181. Furuse, M.; Hata, M.; Furuse, K.; Yoshida, Y.; Haratake, A.; Sugitani, Y.; Noda, T.; Kubo, A.; Tsukita, S. Claudin-based tight junctions are crucial for the mammalian epidermal barrier: A lesson from claudin-1-deficient mice. J. Cell Biol. 2002, 156, 1099-1111. [CrossRef]

182. Tokumasu, R.; Yamaga, K.; Yamazaki, Y.; Murota, H.; Suzuki, K.; Tamura, A.; Bando, K.; Furuta, Y.; Katayama, I.; Tsukita, S. Dose-dependent role of claudin-1 in vivo in orchestrating features of atopic dermatitis. Proc. Natl. Acad. Sci. USA 2016, 113, E4061-E4068. [CrossRef] [PubMed]

183. Farquhar, M.G.; Palade, G.E. Junctional complexes in various epithelia. J. Cell Biol. 1963, 17, 375-412. [CrossRef]

184. Mohammed, J.; Beura, L.K.; Bobr, A.; Astry, B.; Chicoine, B.; Kashem, S.W.; Welty, N.E.; Igyarto, B.Z.; Wijeyesinghe, S.; Thompson, E.A.; et al. Stromal cells control the epithelial residence of DCs and memory T cells by regulated activation of TGF-beta. Nat. Immunol. 2016, 17, 414-421. [CrossRef]

185. Shi, M.; Zhu, J.; Wang, R.; Chen, X.; Mi, L.; Walz, T.; Springer, T.A. Latent TGF-beta structure and activation. Nature 2011, 474, 343-349. [CrossRef]

186. Mulcahy, M.E.; Geoghegan, J.A.; Monk, I.R.; O'Keeffe, K.M.; Walsh, E.J.; Foster, T.J.; McLoughlin, R.M. Nasal colonisation by Staphylococcus aureus depends upon clumping factor B binding to the squamous epithelial cell envelope protein loricrin. PLoS Pathog. 2012, 8, e1003092. [CrossRef] [PubMed]

187. Nishibu, A.; Ward, B.R.; Jester, J.V.; Ploegh, H.L.; Boes, M.; Takashima, A. Behavioral responses of epidermal Langerhans cells in situ to local pathological stimuli. J. Invest. Dermatol. 2006, 126, 787-796. [CrossRef]

188. Bynoe, M.S.; Evans, J.T.; Viret, C.; Janeway, C.A., Jr. Epicutaneous immunization with autoantigenic peptides induces T suppressor cells that prevent experimental allergic encephalomyelitis. Immunity 2003, 19, 317-328. [CrossRef]

189. Walczak, A.; Siger, M.; Ciach, A.; Szczepanik, M.; Selmaj, K. Transdermal application of myelin peptides in multiple sclerosis treatment. JAMA Neurol. 2013, 70, 1105-1109. [CrossRef]

190. Tordesillas, L.; Lozano-Ojalvo, D.; Dunkin, D.; Mondoulet, L.; Agudo, J.; Merad, M.; Sampson, H.A.; Berin, M.C. PDL2(+) $\mathrm{CD} 11 \mathrm{~b}(+)$ dermal dendritic cells capture topical antigen through hair follicles to prime LAP(+) Tregs. Nat. Commun. 2018, 9, 5238. [CrossRef] [PubMed] 
191. Tordesillas, L.; Mondoulet, L.; Blazquez, A.B.; Benhamou, P.H.; Sampson, H.A.; Berin, M.C. Epicutaneous immunotherapy induces gastrointestinal $\mathrm{LAP}(+)$ regulatory T cells and prevents food-induced anaphylaxis. J. Allergy Clin. Immunol. 2017, 139, 189-201.e4. [CrossRef] [PubMed]

192. Irvine, A.D.; McLean, W.H. Breaking the (un)sound barrier: Filaggrin is a major gene for atopic dermatitis. J. Invest. Dermatol. 2006, 126, 1200-1202. [CrossRef] [PubMed] 